\title{
Splitting Definitives: The Separation of the Definite Article in Medieval and Pre-Modern Written Judeo-Arabic
}

\author{
Magdalen M. Connolly \\ Faculty of Asian and Middle Eastern Studies, University of Cambridge, \\ Cambridge $\mathrm{CB}_{3}$ 9DA, UK \\ Mmc53@cam.ac.uk
}

\begin{abstract}
This article explores the reasons behind the orthographic practice of representing the definite article in written Judeo-Arabic as an independent entity, a phenomenon which became widespread in Jewish Arabic-speaking communities in the pre-modern era. Commencing with its representation in fifteenth to nineteenth-century Egyptian Judeo-Arabic manuscripts, the orthographic feature is traced back to Judeo-Arabic texts produced in medieval al-Andalus, Sicily, and the Magrib, and from there, to post1492 CE Sephardī Jewish refugees, who settled in North Africa and Egypt. The phenomenon is revealed to be the result of a two-stage process: (i) direct language contact between Romance and Judeo-Arabic; and (ii) the influence of Judeo-Spanish writing on Judeo-Arabic spelling practices in diaspora communities after their expulsion from the Spanish Kingdoms.
\end{abstract}

\section{Keywords}

Judeo-Arabic - orthography - al-Andalus - Jewish languages - Cairo Genizah Judeo-Spanish 


\section{Introduction $^{1}$}

\section{In the Classical Arabic (henceforth CA) reading tradition and vernacular forms of Arabic, ${ }^{2}$ the lām of the definite article - CA: 'al-; Modern Cairene Arabic (henceforth MCA): 'il- - assimilates ${ }^{3}$ to following coronal consonants (Zemánek}

1 Acknowledgements: An early draft of this article was circulated among my colleagues at the University of Cambridge's Faculty of Asian and Middle Eastern Studies and benefitted from their combined input. I am particularly grateful to Dr. Mila Neishtadt for her insightful comments, and to Nick Posegay for suggesting the title. I would also like to thank Prof. Geoffrey Khan for reading a draft of this article and for offering useful feedback, as always. I am indebted to the two anonymous reviewers for their helpful comments and suggestions. This being said, any errors herein are mine alone. This research was funded by the Leverhulme Trust and the Isaac Newton Trust in the form of a Leverhulme Early Career Fellowship. This article is based on a section of my Ph.D. thesis (Connolly 2018:95-102), and as such was also funded by a 'Le Bas Award,' Cambridge Home and European Scholarship Scheme (cHEss), University of Cambridge. All of the images used here have been reproduced by kind permission of the Syndics of Cambridge University Library.

2 In MCA, it is not only the coronal consonants that assimilate the /l/ of the definite article, but also the two velar stops $/ \mathrm{k} /(k \bar{a} f)$ and $/ \mathrm{g} /(\grave{g} \grave{\imath} m)$.

3 Heselwood \& Watson contend that 'the Arabic definite article does not assimilate' (2013:34). Their argument is predicated upon refined definitions of the terms 'geminate,' 'assimilation,' and 'coarticulation.' The former is divided into three subcategories, comprising on the one hand (i) 'true' geminates, and on the other (ii) 'false' or 'concatenatory' and (iii) 'fake' or 'assimilatory' geminates. A 'true' geminate, as termed by Heselwood \& Watson, is "obligatory, contrasts (at least potentially) with singletons, and displays 'geminate inseparability'" (Gafos 2002:274 in Heselwood \& Watson 2013:38). 'False' geminates arise from the linking of 'two identical consonants, e.g., bad dog,' while 'fake' geminates occur when one consonant fully assimilates to another consonant, e.g., bad boy [bab bor] (examples from Heselwood \& Watson 2013:38). Through the examination of these various types of coarticulation using four words, two speakers and electropalatographic (EPG) data, Heselwood \& Watson demonstrate that the /1/ of the definite article should not be regarded as assimilated by the following coronal consonant, but as 'true' geminates which occur as phonologically-determined allomorphs of the definite article" $(2013: 34,46)$. The one major impediment to this theory is that in MCA when preceding the velar stops $/ \mathrm{g} /$ and $/ \mathrm{k} /$, the definite article may be realized as either [?il] or [?ig]/[?ik]. While Heselwood \& Watson acknowledge this phonetic feature of MCA (2013:47), they do not offer a satisfactory resolution to the issue. Despite this theory's compelling nature, the term 'assimilation' will continue to be used here to describe the phonetic change that occurs to the /1/ definite article when placed before coronal consonants. 
2006:204), e.g., السّماوات 'the heavens' (CA: 'al-samāwāt; CA pronunciation: [?asiama:wa:t]; MCA pronunciation: [?isiamawa:t]). These consonants were referred to by the Arab grammarians as 'al-ḥurūf 'al-šamsiyya 'the sun letters' (as opposed to 'al-hurūf 'al-qamariyya 'the moon letters,' in which the lām of the definite article is retained in pronunciation) (Fischer 2002:26, §44.1). The ال 'al-, irrespective of its immediate phonetic environment (Fischer 2002:11, §18). Where the lām of the definite article is assimilated in the reading tradition, this is indicated by the writing of $\check{s} a d d a \stackrel{()}{()}$ above the following grapheme (ibid.) in vocalized texts (see the previous example).

In written Judeo-Arabic (henceforth JA), ${ }^{5}$ the representation of the definite article varies across the centuries. In their detailed study of early JA documentary papyri, ${ }^{6}$ Blau \& Hopkins note that the lamed of the definite article is always omitted preceding coronal consonants, e.g., ארחים 'the Merciful One' (CA: 'al-rahīm) I, line 1; II, line 1; XIII, line 1); אדוניה 'the world' (CA: 'al-dunyā) (II, line 1; III E, line 2) (examples from Blau \& Hopkins 1987:148). In classical JA, however, the writing of the definite article follows written CA convention and appears in full (and often in ligatured) form (i.e., אל 'l-/'l 'the'), regardless of the phonetic realization of the following consonant, e.g., אלסחר 'the magic' (CA: 'al-siḥr) (CUL T-S NS 298.55, 1 recto, line 6, ca. eleventh century CE); אַלסְמְוַאת 'the heavens' (CA: 'al-samāwāt) (CUL T-S Ar. 8.3, recto, line 14) (example from Khan 2010:202; see also Hary 1996:730; Khan 2016:396-397). This classical JA practice is continued in the late JA period, with one major difference:

4 The transliteration used here and elsewhere represents the written CA spelling, rather than the phonetic realization. Where phonetic transcriptions are used, they are bounded by square brackets [].

5 Written JA is generally categorized into three periods: early JA (ninth-tenth centuries CE); classical JA (tenth-fifteenth centuries CE); and late JA (fifteenth-nineteenth centuries CE) (Khan 2007). This categorization is based on orthographic developments, of which the representation of the definite article, discussed here, is an important feature. For an alternative categorization of JA, which combines written and spoken manifestations of JA, see Hary 1992, 2009. In using the term 'Judeo-Arabic,' I do so in reference to written manifestations of the language, following the example set by Khan (2007) to mean simply 'Arabic written in Hebrew script.' For a recent discussion of spoken JA dialects, see Khan (2018).

6 Blau \& Hopkins (1984) differentiate between scribes educated in CA and those ignorant of its principles; the former used classical JA spelling before the tenth century, while the latter universally favored early JA spelling (which Blau \& Hopkins state was based on Hebrew and Aramaic spelling practice). Ackerman-Lieberman has convincingly challenged this dichotomy, instead suggesting that the type of spelling used may be determined by the urban/rural divide present in many Arabic-speaking countries at the time (2014:158-159). Most of Blau \& Hopkin's observations about early JA spelling are based on papyri found in al-Ašmūnayn, a town situated in the Nile Delta (ibid.:158). 
the definite article is regularly written independently of the noun or adjective it modifies (Khan 1992:231, 2006:51, 2010:211; Hary 2009:110, §1.15; Wagner 2010:6, §4.7.1). ${ }^{7}$

Although the definite article's transformation into a separate entity ${ }^{8}$ is an oft-noted feature of eighteenth and nineteenth-century JA texts (see, for example, Khan 1992:231, 2006:51; Wagner 2010:66-67), to the best of my knowledge, the cause of its separation has yet to be explored. A potential explanation - twofold in nature - for this orthographic development is proposed in this article. Commencing with a brief examination of the definite article's representation in late Egyptian JA folk tales and letters (§2.1), I then examine orthographic precedents for the separation of the definite article in Arabic and JA texts (\$2.2). While this exploration provides some significant insights into an orthographic practice that may have precipitated this phenomenon's emergence, it does not offer a comprehensive solution. Thus, I turn my attention to pre-seventeenth-century texts which display this phenomenon,

7 Wagner also records two instances in eleventh-century letters (which she attributes to Egypt and the Magrib, respectively) in which the definite article is written as an independent entity (2010:66, §4.7.1). The first of these (CUL T-S 13J17.3) was written by Efrayim b. Isma'îl al-Ǧawharī, a merchant based in Alexandria, but most probably of Mag̉ribī origin (see Appendix, Table 3, number 85). The second letter (CUL T-S 12.218) contains consistent separation of the definite article from the noun it modifies. This trader's letter - dated to 'the sixth of šawwāl, the year four hundred and eleven' (i.e., 23 January $1021 \mathrm{CE}$ ) is written in a distinctly Sephardī script-style (complete with ligatures for final heh) and contains references to Cordoba and the Berbers (see recto, lines 18-19). I, therefore, suggest that this text may be more reflective of Andalusī writing practices than Magiribī standards of the day. I am grateful to Dr. José Martínez Delgado for discussing my doubts about the Mag̉ribī origins of this text with me.

8 The definite article is categorized as an independent entity here when the space between it and the noun or adjective it governs is equidistant to other morphologically discrete units. So, for example, in the hand of Isma'îl b. Ishạa Al-Andalusī (see Appendix, Table 1, number 2), the definite article is consistently separated from its noun or adjective by a space of approx. $0.2 \mathrm{~cm}$; the same distance which separates the majority of words from one another in this writer's letters (see, for example, CUL T-S 10J12.5, recto, line 6). Meanwhile, Efrayim b. Ismacill al-Ǧawhari’s (see Appendix, Table 3, number 85) writing has been described as displaying a tendency towards separation because, in some instances, the distance between the definite article and its noun is equidistant $(0.2 \mathrm{~cm})$ with that between the preceding preposition and the definite article (e.g., CUL T-S 13J17.3 recto, line 6), but more often than not, the definite article is written attached to the noun it modifies, or is at least only $0.1 \mathrm{~cm}$ apart from the following noun, rendering it closer than other independent morphological units. In those letters which are listed as not containing an independent definite article, the space between the definite article and its noun or adjective is consistently less than the space between morphologically distinct units (see, for example, CUL T-S 13J25.6, written in the hand of Halfon b. Menašše b. al-Qațāiif (for other letters and documents by the same scribe, see Appendix, Table 4, number 115)). 
leading me to explore the potential influence of Romance orthography on the writing practices of Andalusī Jews in the medieval era (§2.3). In a quest to understand the phenomenon's emergence as a stable feature of postseventeenth century written Egyptian JA, I also examine the potential impact of Judeo-Spanish (henceforth Js) on Egyptian JA writing practices post-1492 CE $(\S 2.4)$. I contend $(\S 3)$ that the definite article's emergence as an independent entity in written JA was a twofold process. The first stage was borne of direct contact with Romance dialects and extended to areas of the Magrib with close ties to Al-Andalus. The second stage of the process was a consequence of the mass migration of Sephardī Jews from the Iberian Peninsula after $1492 \mathrm{CE}$, the influence of whom (at least in this regard) is felt as far east as Baghdad.

\section{The Definite Article's Representation in Late JA Folk Narratives and Letters ${ }^{9}$}

The dawn of the fifteenth century is generally considered a turning point in JA orthography (see Khan 2007; ${ }^{10}$ Hary 1992, 2009); it signifies the close of the classical JA period, in which JA spelling practices were primarily informed by CA, heralding the advent of an alternative writing style, often designated 'Hebraized' in contemporary scholarship (see Hary 1997:37, 2009). This 'Hebraized' manifestation of written JA is generally considered to be a combination - in varying degrees - of increased Hebraisms ${ }^{11}$ and phonetic features on the one hand, and the retention of aspects of established classical JA writing practices on the other. ${ }^{12}$

$9 \quad$ Hary refers to two examples from the seventeenth-century text Darke No'am in which the lamed of the definite article is omitted when preceding a coronal consonant, e.g., אצגירה 'the small (f.)' (CA: 'al-ṣagìra); אנאס 'the people' (CA: 'al-nās) (examples from Hary 1992:92). However, instances of this phenomenon seldom occur in other late JA texts and not at all in the corpora under examination here.

10 It should be noted that the shift from classical to late JA orthography occurs in different geographical regions at different times (see Avishur 1986:3 regarding the situation in Iraq) and - in the case of Yemen - not at all (Khan 2018:150, 154). Here, the main focus is on Egyptian written JA.

11 The Hebraisms - derived from Rabbinic Hebrew orthographic norms - include: (i) the representation of consonantal waw and $y \bar{a}^{3}$ with double vav and double yod, respectively; (ii) increased plene spelling of the short vowels /i/ and /u/; (iii) and the representation of final long /â/ with heh rather than 'alef or yod.

12 While the influence of Rabbinic Hebrew writing practices on late JA orthography is clearly discernible, it is possible that direct Arabic influences, most notably in the use of the diacritical dot, have been overlooked in JA scholarship (Connolly 2018). 
A brief survey of late JA texts - dating from the fifteenth to nineteenth centuries - is necessary to: (i) determine the approximate date at which the writing of the definite article as a separate entity becomes a common phenomenon in Egyptian JA texts; and (ii) qualitatively assess the regularity of the feature's use after this date. The following sections summarize findings regarding this feature in (i) fourteenth/fifteenth- and sixteenth-century and (ii) eighteenth- and nineteenth-century JA folk tales and letters.

\section{Fourteenth/Fifteenth- and Sixteenth-Century Folk Tales}

The ligature of the definite article is consistently attached to the noun (or adjective) it modifies in these folk tales, e.g., ואלסאבק 'and the former' (CA: wa-'-sābiq) (Firk. Evr.-Arab. II 1528, 1 recto, line 5); אלתעלב 'the fox' (CA: 'al-talab) (Firk. Evr.-Arab. II 852, 2 recto, line 5); אלשאב 'the youth' (cA:'al-šabb, 'al-šābb) (Firk. Evr.-Arab. I 2996, 14 recto, line 2).

\section{Late Fifteenth-Century Letters}

In all three letters written by Egyptian hands (Bodl. MS Heb.c.72/13, Bodl. MS Heb.c.72/39 and CUL T-S 13J26.7), the definite article is attached to the noun or adjective it refers to, e.g., אלכתאב 'the letter' (cA:'al-kitāb) (Bodl. ms Heb.c.72/13, recto, line 13); אלגואב 'the reply' (CA: 'al-ğawāb) (Bodl. Ms Heb.c.72/39, verso, line 10); אלסלאם אלתאם 'the perfect greetings' (CA: 'al-salām 'al-tāmm) (CUL T-S 13J26.7, recto, line 20). However, in the contemporaneous letter Bodl. MS Heb.c.72/18, which was sent from Syracuse, Sicily, and appears to have been composed by a Sephardī trader, ${ }^{13}$ The definite article is consistently detached from its noun, e.g., ואל נאס 'and the people' (CA: 'al-nās) (Bodl. Ms Heb.c.72/18, recto, line 6); אל נצראני 'the Christian' (CA: 'al-nașrānī) (Bodl. Ms Heb.c.72/18, recto, line 11).

\section{Eighteenth- and Nineteenth-Century Folk Tales}

In the eighteenth/nineteenth-century folk tale AIU VII.C.16, the definite article is written as a separate entity, e.g., ואל קמח ואל בייץ ואל זבדא 'and the wheat, eggs, and butter' (CA: wa-'l-qamh wa-'l-bayd wa-'l-zubda) (AIU VII.C.16, recto, lines 18-9) (see Connolly 2020). The same is true in contemporaneous folk tales, e.g., אל וולד 'the boy' (CA: 'al-walad) (cul T-S Ar. 46.10, recto, line 35); דעווה 'the appeal' (CA: 'al-da'wa) (BnF Hébreu 583, 138 recto, lines 9, 17, 19, 138 verso, line 5).

13 This letter contains the Andalusī Arabic construct state marker matāc 'of' (rendered מתע / מתע)/ מתע in JA), and the purposive subordinating conjunction bā̌s 'in order to' (באש). These two features are hallmarks of Andalusī Arabic (see Corriente 2006: §2.2.3.2 and §2.2.3.6). 
However, in the late nineteenth-century folk tale NLI Cairo JC 104, the definite article is often (but not consistently) written attached to the following noun or adjective, e.g., אלאנסאן 'the people' (CA: 'al-'insān) (NLI Cairo JC 104, 13 recto, lines 1 and 2). ${ }^{14}$ The writing of the definite article attached to the following noun in NLI Cairo JC 104 may indicate a greater awareness of Arabic orthographic practices with regard to the definite article and (perhaps) a desire to replicate the written Arabic norm. ${ }^{15}$

\section{Eighteenth/Nineteenth-Century Letters}

The definite article is regularly written as an independent morpheme in late JA letters, e.g., אל ביע ואל שרה 'the buying and selling' (CA: 'al-bay'wa-'l-širä') (Manc. Rylands Lig2, 1 recto, margin 3); אל נאס 'the people' (CA: 'al-nās) (CUL T-S 13J25.24, 1 verso, col. 1, line 25); אל דורה 'the maize' (CA: 'al-dura) (CUL T-S 10J16.35, 1 recto, line 26 ).

All the Egyptian JA folk narratives and letters from the fourteenth/fifteenth and sixteenth centuries adhere to the classical JA (and Arabic) practice of attaching the definite article to the following noun or adjective. This practice has all but been abandoned in the eighteenth- and nineteenth-century Egyptian folk tales and letters in favor of the definite article's representation as an independent entity. ${ }^{16}$ Thus, the seventeenth century (approximately speaking) would appear to be the period in which this orthographic shift became widely adopted among Egyptian Jewish writers. As can be seen, however, from its occurrence in the Sephardī letter, Bodl. Ms Heb.c.72/18 (see above), this phenomenon predates the seventeenth century. Does this constitute an idiosyncratic quirk of a Sephardī Jewish Arabic-speaking merchant, or is it

14 This is only the case, however, when the definite article is not preceded by the bound morphemes $b i$ - 'in, with' (CA: $b i$-) or li- 'to, for' (CA: $l i-)$. In such cases, the definite article forms a separate entity with the bound morpheme, e.g., באל אסל 'in the name' (ca: bi-'-'-ism) (NLI Cairo JC 104, 2 verso, line 5); באל טוראב 'with the earth' (CA: bi-'l-turāb) (NLI Cairo JC 104, 7 recto, line 12). This practice is common to all late JA texts that I have examined.

15 It seems, however, that this adherence to Arabic orthographic norms is the exception rather than the rule in eighteenth to twentieth-century JA texts. The tendency to write the definite article as an independent entity is evident even in printed JA material from Baghdad in the early twentieth century CE.

16 Unfortunately, we do not have at our disposal JA texts that can be confidently dated to the seventeenth century CE. 
perhaps indicative of a more widespread writing practice, prevalent among Sephardī Jews?

\section{Orthographic Precedents in Arabic and JA}

In early Arabic documentary and literary texts, division of words at the end of a text line is a common phenomenon. Borne of a desire to ensure a rectangular written area, with four neat sides (Gacek 2012:146), it was superseded by the elongation $(m a s ̌ q)$ or contraction ( ğam $^{\prime}$ ) of letters, or the superscription ( $t^{c} c^{\prime} \bar{q} q$ ) of the final word(s) of a line (ibid.). The latter practice was particularly prevalent in the Eastern tradition, while the former found favor in the Magrib. The scribes of earlier texts in which word division is frequently encountered at the end of the text line do not seem to have been concerned with morphological boundaries, so much as with aesthetic uniformity. Yet, the practice of separating words for the purposes of textline justification is not as arbitrary as it may first appear; only those graphemes which do not connect to the following grapheme by means of a ligature - such as 'alif, $w \bar{a} w, r \bar{a}$, etc. - are used for this purpose. Thus, in an early hiǧäzī-script copy of the Qurān, BnF Arabe 328(a), recto, lines 13-14, we find the lone 'alif of the definite article positioned at the end of the text line, while its lām sits at the start of the following text line, connected to the word it modifies (for similar examples of this phenomenon, see Figs. 1 and 2).

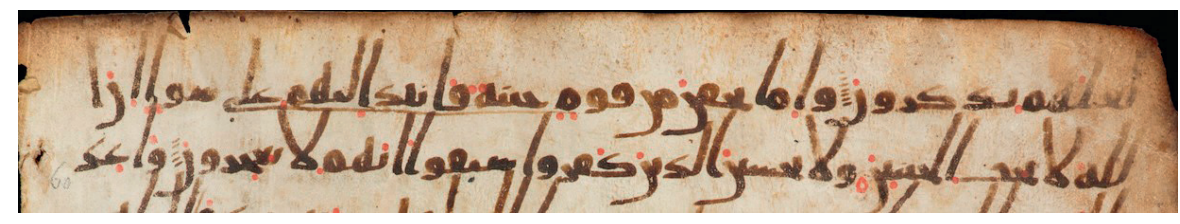

FIGURE 1 CUL MS Add. 1125, f2 verso, lines 1-2: A section of an eighth-century CE Qurān fragment, written in vertical format on parchment (Qur’ān 8:57-6o) ${ }^{17}$

17 These lines read as follows:

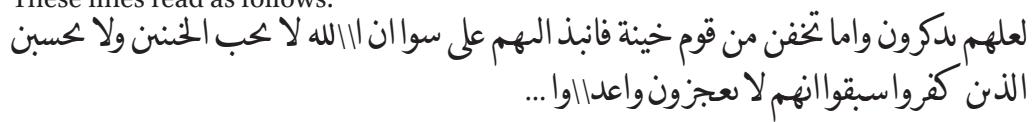




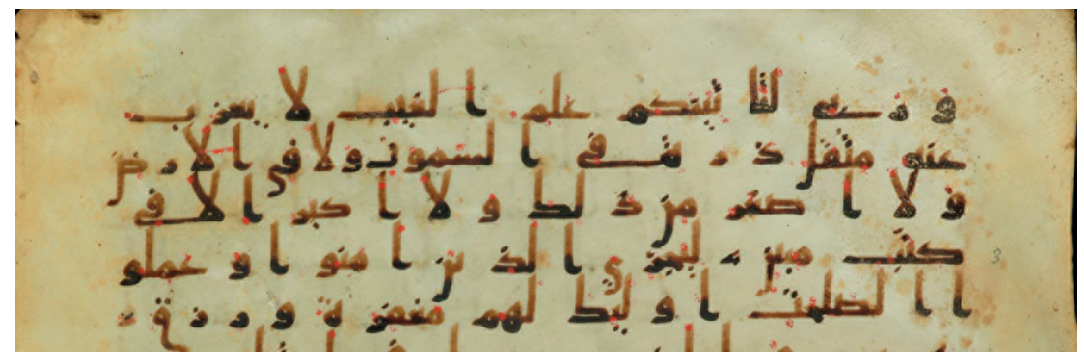

FIgURE 2 CUL MS Add. 1146, f2 verso, lines 1-5: A section of a vocalized eighth/ ninth-century CE Qur’ān, written in vertical format on parchment (Qur’ān $34: 2-4)^{18}$

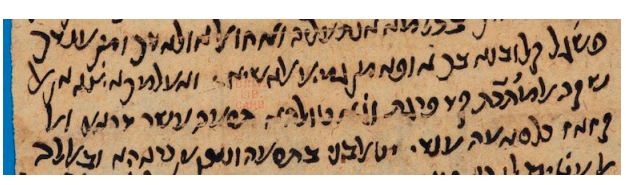

FIGURE 3 CUL T-S 13J20.22, recto, lines 19-20:

Section of a letter written by Halfon $b$.

Menašše b. al-Qațāif on behalf of the daughter of Hillel b. 'Eli' ${ }^{19}$

The same preoccupation with text line justification is apparent in some JA manuscripts. Hebrew graphemes, however, are inherently independent; they are not connected to one another with a ligature. Therefore, the points at which a word may be divided are as many as there are letters. It is noteworthy, therefore, that the division of the word in JA texts most often occurs at the point at which the definite article ends and the noun or adjective it modifies begins; the 'alef and lamed of the definite article - written as a single entity, often ligatured - are positioned at the end of the text line, while the noun or adjective is written at the start of the following text line (see Fig. 3).

This tendency to separate the definite article and noun from one another for the purposes of textline justification may be indicative of its perception as a morphologically distinct entity. This same tendency may also motivate the orthographic practice of writing the lām (or lamed) of the definite article, even when it is assimilated, in CA (and JA). However, while this representation of the

18 The manuscript reagds as follows:

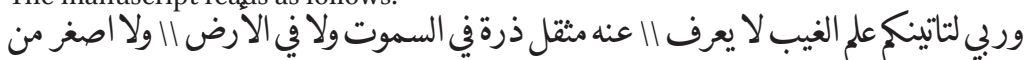

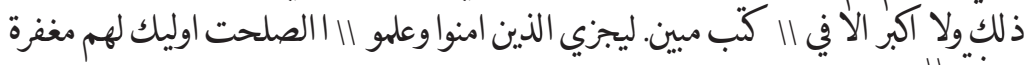

19 For another example of this phenomenon, see Bodl. Ms Heb.d.11/9, recto, lines 30-32, a letter written by (Abū Zikrī) Yahūda b. Sa'adya ha-Rofe. 
definite article in classical JA texts may grant us some insight into how the definite article was perceived among Arabic-speaking Jews in the medieval era, it does not answer the question of how the independent definite article emerged as a standard feature of post-seventeenth-century Egyptian JA texts. To answer this question, it is necessary to delve further into the history of orthographic representations of the JA definite article, beginning with the earliest evidence of this phenomenon that we have encountered so far, namely, the fifteenthcentury JA letter Bodl. ms Heb.c.72/18.

\section{Al-Andalus, Romance Orthography, and Sephardī Jews}

Bodl. MS Heb.c.72/18 is found among a cache of letters addressed to Mošeh b. Yahūda ${ }^{20}$ in Alexandria. Amongst these letters, which predominantly appear to be sent from Cairo and the Magrib, there is at least one other letter composed in the most westerly regions of the Arabic-speaking world (Bodl. Ms Heb.c.72/23), but by a different hand to that found in Bodl. MS Heb.c. $72 / 18 .{ }^{21}$ In both letters, the definite article is consistently and clearly written as an independent entity, e.g., אל ספר תורה 'the book (of the) Torah' (Bodl. Ms Heb.c.72/23, 1 recto, line

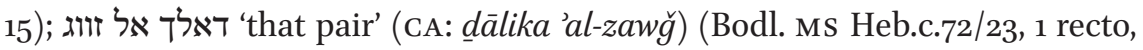
line 22). This suggests that the practice of separating the definite article from its noun is not unique to the author of Bodl. Ms Heb.c.72/18, but may, in fact, constitute a more widespread orthographic convention. In order to ascertain the extent of its use, I surveyed the autographs of known Sephardī Jews in the Cairo Genizah collections.

A brief examination of the autographs of two renowned Sephardi Jews Yahūda ha-Levi (ca. 1075/1086-1141 CE) and Mošeh b. Maimon (Maimonides) ${ }^{22}$ (ca. 1135/1138-1204 CE) - reveals that the representation of the definite article as a separate entity predates the late fifteenth/early sixteenth-century letters mentioned above. As can be seen from the following examples (see Figs. 4-8), this phenomenon occurs sporadically in both ha-Levi (Figs. 4-6) and Maimonides' (Figs. 7-8) autographs.

$20 \quad$ See Arad \& Wagner (forthcoming).

21 The contemporaneous texts Bodl. MS Heb.c.72/2 and Bodl. MS Heb.c.72/24, composed by the same hand and possibly fragments of the same text, display intermittent separation of the definite article from the noun, e.g., אל חכמיר 'the sages' (Bodl. Ms Heb.c.72/2, 1 verso, line 12); אל כאמל אל אכיר 'the final perfection' (Bodl. Ms Heb.c.72/2, 1 verso, line 8); and and in the Torah' (Bodl. Ms Heb.c.72/24, 1 verso, line 9).

22 I would like to thank Dr. Mila Neishtadt for pointing me in the direction of Maimonides via Blau (1980). 


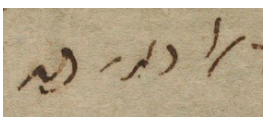

FIGURE 4

' אל ראי פי 'the opinion on ...' (CUL T-S 8J18.5, recto, line 10)

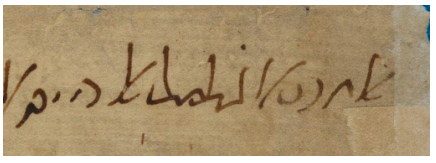

FIGURE 5

the honorable sage, the head ...' (CUL T-S 8J18.5, verso, line 1)

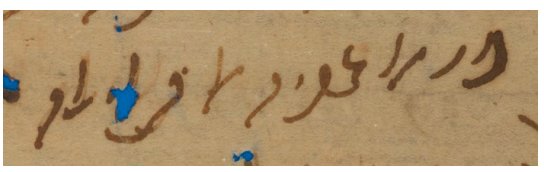

FIGURE 6 פי אל בקיה אל קלילה a.... among the remaining few ...' (CUL T-S 10J15.1, recto, line 5)

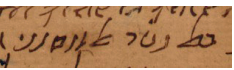

FIGURE 7 באל נטר אלאנסאני '... in human sight ...'23 (CUL T-S 10Ka4.1, f2 recto, line 2)

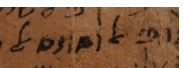

FIGURE 8 ופי אל וסואס 'and in the temptation ...' (CUL T-S Ar.21.112a, fi recto, line 5)

To assess the veracity of these preliminary impressions, I expanded this search to encompass individuals whose documents are preserved in the Cairo Genizah collections and about whom we have some biographical data (see the Appendix for Tables 1-4). ${ }^{24}$ The Tables list some 125 Jewish individuals of (i) Andalusī and Sicilian (Table 1), (ii) Mağribī, (Table 2), (iii) Alexandrian (Table 3), and (iv) Egyptian, Palestinian, and Iraqī (Table 4) origins, noting the

23 Here, the first ligatured definite article (prefixed with the preposition bi-) is written independently of the following noun, while the following definite article is attached to the noun.

24 The data available are often very limited. I have relied heavily on the historical works of Stillman (1973), Ben-Sasson (1976), Cohen (1980), Gil (1992, 1997), Simonsohn (1997), and Goldberg (2012) for much of this information. Where available, I have also used the writer's nisba - such as 'al-Andalusī 'the Andalusian' - mentioned in the letters. This is by no means proof of the writer's geographical origin, as it may refer to a historical-geographical association belonging to a previous generation of his/her family, but it is used here in the absence of other details. 
classmarks which have been attributed to them, and whether or not the definite article is written as a separate entity in their letter(s) and documents.

The overall trends revealed by this search confirm that the separation of the definite article was not simply an orthographic peculiarity of ha-Levi and Maimonides or the two fifteenth-century merchants, but was a widespread orthographic practice among Andalusī and Sicilian Jews (see Table 1, individuals $1-31$ ).

The propensity towards writing the definite article as an independent entity is also evident among Mag̉ribī Jews, albeit to a lesser extent (see Table 2, individuals 32-84). A little over half of the Magribī writers consistently separate the definite article from the noun/adjective in their letters. In some of the texts (approximately $30 \%$ ), the writers seem uncertain of the definite articles' status, sometimes writing it as a separate entity, sometimes as a bound morpheme. The remaining minority (approximately $15 \%$ ) write the article attached to the noun/adjective.

Of those letter-writers who lived and worked in Alexandria ${ }^{25}$ (see Table 3, individuals 85-92), three merchants wrote the definite article as an independent entity, while the remaining five veered between attached and detached representations of the definite article.

The final category (Table 4, individuals 93-125) contains letters from merchants and Jewish notables who lived in Egypt, many of whom emigrated from Iraq, Palestine, or present-day Syria as adults. Of these, only two separated the definite article from the noun/adjective (see Table 4, numbers 108, and 122), while another individual showed an inconsistent representation of the definite article (see Table 4, number 121).

This review of the Sephardī, Magiribī, Egyptian, Palestinian, and Iraqi Cairo Genizah documents indicates that the separation of the definite article from the noun/adjective it modifies was an enduring practice among Sephardī and - to a lesser extent - Magiribī Jews. Yet, we are still no closer to understanding the motivation behind the phenomenon's development. In order to do so, it is necessary to examine the emergence of the Romance languages in the Iberian Peninsula.

The early Romance dialects - which gradually fragmented and evolved into the independent languages Catalan, Spanish, French, Romanian, Portuguese,

25 It is probable that some of the individuals included in this category - such as Efrayim b. Isma'il 'al-Ğawharī (see Appendix, Table 3, number 85) - were in fact of Maǵribì origin. However, as little is known for certain about their birthplace and educational backgrounds, I have included them in this category. 
and Italian - are documented in written form ${ }^{26}$ as early as the eighth and ninth centuries CE (see Frank-Job \& Selig 2016:24, 27). Therefore, the spoken forms are thought to have emerged as early as the seventh - mid-eighth centuries CE (see Herman 1996 for a discussion of the geographical differences in the development of Romance languages). ${ }^{27}$ Whether these early manifestations of the Romance dialects were considered independent of Latin by their native speakers and writers is much discussed (see Wright 1976, 2016; López-Morillas 20oo; Ledgeway 2012; and Clackson 2016), but for our purposes, it is sufficient to state that Romance dialects were in circulation in the Iberian Peninsula prior to the Islamicate conquest of the region in $711 \mathrm{CE}$.

More specifically, one of the most fundamental linguistic innovations of Romance languages - namely, their independent definite and indefinite articles, ${ }^{28}$ conspicuously absent in their predecessor language, Latin - was also either established or at the very least inchoate in the early eighth century CE (Ledgeway 2012:89-105; Ramat \& Ricca 2016:52-53; Giusti 2016:551). When the feature came into wide circulation is a source of much contention; some scholars suggest that its relative morphological uniformity and functionality within the varieties of Romance languages indicates its emergence ca. sixth century CE (Giusti 2016:552); while others - on the basis of the extant written evidence - claim that it did not develop until the eighth century CE (Ledgeway 2016:766; see also Adams 2013). Yet, it is evident that it was at least incipient on the eve of the Islamicate conquest in $711 \mathrm{CE}$.

Thus, while little is known for certain about the language situation of Al-Andalus during the period of Muslim rule, and scholarly consensus regarding the interpretation of the scant evidence at our disposal is far from being achieved (Zwartjes 2006), ${ }^{29}$ we can establish with (relative) certainty that pre$711 \mathrm{CE}$, the inhabitants of the Iberian Peninsula - Christians, Jews, and Berbers,

26 These early eighth to late tenth century CE instances of written Romance vernaculars constitute snippets (such as riddles, anecdotes, glossaries, lists, and marginalia) within Latin texts. It is not until the mid-twelfth century CE that Romance texts are available on a larger scale (Frank-Job \& Selig 2016:24). On the important distinction between written and spoken manifestations of the language, see Clackson (2016); and Wright (2016).

27 Even the most conservative estimates regarding the development of the Romance dialects place them in the early ninth century (Ledgeway 2012:1, n.2).

28 The various iterations of the definite article - el/la (Catalan/Spanish); le/la (French); il/ la (Italian), and so forth - are derived from the Latin demonstrative pronoun ILLE 'that' (Ledgway 2016:765; for those Romance languages whose definite article derives from Latin IPSE, see Ledgeway 2012:89-105; Ramat \& Ricca 2016:52-53; Ledgeway 2016:765).

29 It is also worth bearing in mind that of the extant evidence the majority pertains to the elite, be they Christian, Jewish, or Muslim. 
alike - spoke early Romance dialect(s). The literate among them likely wrote Romance and Latin (Wasserstein 1991:4).

In $711 \mathrm{CE}$, the invading troops comprised Muslim Arabs, Jews from North Africa and the Arabian Peninsula, and - by far the largest component Berbers. ${ }^{30}$ As such, a multilingual situation arose in Al-Andalus, in which the conquering Muslim elite spoke Arabic (as a minority), Berber, and (perhaps) a Romance dialect, while the conquered Christians, Jews, and native Berbers spoke Romance dialect(s). ${ }^{31}$ This heterogeneous linguistic situation is partially reflected in the issuing of bilingual Arabic-Latin coins in the earliest years of the conquest (Gallego 2003:110-111) and that circulated for some time after the initial invasion (Thompson 1971:68 cited in Zwartjes 2006); the inclusion of Latin, a concession to the realities of the linguistic situation in which the vanquishers found themselves; the use of Arabic, a declaration of their intention that it would one day dominate.

How rapidly this ambition was realized remains uncertain. It is welldocumented that no notable post-tenth century CE Latin texts survive (Wasserstein 1991:5; Gallego 2003:127) (and, by inference, may not have been produced, at all). That the Arabic language came to be held in high regard by the indigenous inhabitants of the Iberian Peninsula by the ninth and tenth centuries CE is evident from the translation into Arabic of the Psalms (pre c. $889 \mathrm{CE}$ ) and the Gospels (946 CE) (López-Morillas 2000:49); its mastery by eminent members of the Jewish community, such as the celebrated Ismail b. Nagirila (d. ca. 1056 CE) (Bennison and Gallego 2010:146), and, later, Ibrahīm b. Sahl al-Išbilì (d. $1251 \mathrm{CE}$ ); and the extensive production of grammatical, philosophical, poetic, and scientific texts written in Arabic by Christians and Jews alike during the tenth to thirteenth centuries CE. Scattered references in primary sources, in which contemporaries bemoan the loss of Latin knowledge among the Christian inhabitants of Al-Andalus (see, for example, Alvarus of

30 As to whether the conquering Berbers spoke Arabic already, there is currently no definitive answer. Some scholars have suggested that, in addition to Berber, some of the conquering Berber tribes may have spoken a Romance dialect (Wasserstein 1991:4; Gallego 2003:119). However, few seem to suggest that the Berbers would have already been Arabic-speaking at the time of the invasion, and recent scholarship has challenged the assumption that they would have undergone the process of Arabization immediately after the conquest (see Kossmann 2013:76-85 for a survey of early Berber terminology produced to explain Islamic concepts. This terminology's existence implies that an immediate shift to Arabic by Berbers who converted to Islam cannot be assumed; see also López-Morillas 2000:4041 for a brief summary of recent research in this area).

31 López-Morillas states that the Jews of Al-Andalus were quick to adopt Arabic, while simultaneously "retain[ing] their hold on Romance" (ibid.:42-43), although he offers no evidence for this assertion. 
Cordoba's (d. $861 \mathrm{CE}$ ) frequently referenced passage in Indiculus Luminosus (cited in Wasserstein 1999:3, who expresses understandable reservations about this text's interpretation; see also Gallego 2003:127)) have been interpreted as confirmation of early Arabization (ibid.:131).

The lack of post-tenth-century Latin sources originating from Al-Andalus does not necessarily preclude the continued use of spoken and written Romance dialects, at least among some strata of society. There is evidence suggesting that Romance was spoken - or at least written - in areas of Al-Andalus throughout the tenth and eleventh centuries. The most oft-cited manifestation of the continued awareness and use of Romance in written form is the muwaššah, a manifestation of strophic poetry (the other being zağal, written in colloquial Arabic), for which Al-Andalus' Muslim and Jewish elite were famed (Gallego 2003:129-130; Rosen 2000:165-166). Within these final verses (referred to as the karğa 'departure') of these CA or - in the case of some of the Jewish community - Hebrew poems, are found a couple of lines written in Andalusī Arabic, Romance, or a combination of the two languages (Barletta 2012:769; Rosen 2000:165). Another example of the inclusion of Romance vocabulary in an Arabic-language text is Ibn Baklarish's Kitāb al-'adwiya 'l-mufrada li-'l-Isrä̀il̄ (commonly referred to as Kitab 'al-Musta in̄ī) (see Khan 2008:95-96). ${ }^{32}$

Suffice it to say, ${ }^{33}$ that the Romance languages' definite articles' superficial similarity with the Arabic definite article (pronounced -il in some dialects) is conspicuous. The pre-existing tendency in early JA texts to separate the definite article from its noun for text line justification (see above) may have emphasized its morphological distinctiveness, leading the erudite Jewish writers of JA texts to separate it consistently, irrespective of its place on the text line. As this fashion appears to have been prevalent among the Jewish elite, it is not surprising that it gained currency and was adopted among those who may not have had intimate, first-hand knowledge of Romance dialects.

However, it is clear from Tables 1-4 (see Appendix) that while some Magiribì merchants embraced this orthographic innovation, it was not prevalent among

32 The work is thought to have been composed ca. $1100 \mathrm{CE}$, and the earliest extant copy is a privately owned manuscript (referred to as the Arcadian Library manuscript), dated 1130 CE (Burnett 2008). For a discussion of the Romance and Latin elements in this text, see Villaverde Amieva 2008.

33 It is not my intention to resolve the issue of Al-Andalus' uncertain linguistic situation. Nor do I claim that the potential influence of Romance orthography on the representation of the definite article in JA as a separate entity should be regarded as evidence for the continued use of Romance languages in Al-Andalus. It is possible that the feature emerged during the tenth or even ninth century, during a period of bilingualism, and was retained by Jews long after they ceased to write or speak Romance dialects. 
Egyptian Jews in the Middle Ages. ${ }^{34}$ Therefore, we must keep searching for the reason(s) as to why it became a popular feature of post-seventeenth-century JA texts in the eastern regions of the Arabic-speaking world.

\section{The Expulsion of Sephardī Jews from Spain}

The expulsion of Muslims and Jews from the Castilian and Aragonese Spanish kingdoms in $1492 \mathrm{CE}$ led to a large influx of Spanish-speaking refugees in North Africa, Egypt, and Palestine - estimates vary between 40,000 to 100,000 Sephardī Jewish refugees who arrived in Morocco and then dispersed across the Magrib towards Egypt and Palestine. ${ }^{35}$ It is thought that the majority of Sephardī Jewish refugees hailed from the Catholic province of Toledo (conquered in $1085 \mathrm{CE}$ ) rather than the Muslim kingdom of Granada (which fell only in $1492 \mathrm{CE}$ ). Thus, it is likely that many of them spoke a Spanish or Castilian dialect rather than the Andalusi Arabic dialect prevalent in Granada (Heath 2002:10-11). Spanish, or JS, continued to be spoken among these refugees for at least two centuries after they arrived in the Magrib, Egypt, and Palestine (Kraemer 1991:246). It is even recorded that some Jewish families in northern Morocco carried on using JS amongst themselves until the early twentieth century (Heath 2002:11). As for evidence of written Js (i.e., Spanish written in the Hebrew script), this exists both pre-and post-1492 CE (see Minervini 1992; Penny 2000; Schwarzwald 2004; and Bunis 2011, 2016). ${ }^{36}$ The Cairo Genizah collections alone comprise Js letters, legal documents, responsa, medical texts, piyyüt, and biblical commentaries. ${ }^{37}$ Although slight in number, these texts,

34 Or at the very least, that this feature was not prevalent among those eastern educated Jews whose texts were deposited in the Ben 'Ezra synagogue's genizah.

35 Prior to the $1492 \mathrm{CE}$ Edict of Expulsion, Jews had already begun to travel from Spain to Arabic-speaking lands due to persecution at the Catholic authorities' hands (Beinart 2002:2).

36 While pre-1492 CE Js texts contain Hebrew and Aramaic vocabulary and are written in Hebrew script, it has been demonstrated that the language (morphology, syntax, lexicon, and limited phonology) did not differ from the dialectal varieties of Christians (see Minervini 1992). It is only after the expulsion of the Jews from the Iberian Peninsula that Js developed its own characteristics: retaining archaic features that ceased to be used elsewhere in Spanish-speaking societies; innovating; and dialect-mixing among Sephardī Jewish refugees from different areas of Spain settling in new regions with one another (see Penny 2000:176-192).

37 This observation is based on a brief survey of Js material in the Cairo Genizah collections on the Friedberg site. A more comprehensive search of the Genizah's contents would, I'm sure, reveal more variety, and perhaps even a greater number of Js texts. 
dating from the late fifteenth to eighteenth centuries, attest to the continued use of written Js among Sephardī Jewish refugees in a variety of genres for several centuries after their expulsion from the Iberian Peninsula (Gutwirth 1990:113).

Considering this prolonged period of contact, it is not unreasonable to presume that the customs of written Spanish, or at least written Js, may have influenced the writing practices of JA. ${ }^{38}$ In Spanish, the m.sg. definite article $e l$ is always separate from the noun it modifies, e.g., el dia 'the day.' In Js texts written in the fourteenth/fifteenth and sixteenth centuries (and later), $e l$ is transcribed איל ' איל קיטאדו , איל (the its independent form is retained in Js, e.ge aforementioned' (Spanish: el citado) (Penn. CAjs Halper 408, 1 recto, line 3, ca. 1400-1499 CE); איל דיאה 'the day' (Spanish: el día) (Penn. CAJs Halper 409, 1 recto, line 6, ca. 1400-1700 CE);39 איל גוי 'the gentile' (Yoreh Deah 53, line 25, Salonica 1595); and איל פאנדירו the tambourine' (Spanish:el pandero) (Bet Yosef 8, line 5) (the latter two examples are taken from Benaim's work (2012:192-193; 407-408) on sixteenth-century responsa); איל קוידאדו 'the caution' (Spanish: el cuidado) (CUL Or. 1080J194, 1 recto, line 15) (see Gutwirth 1986:212-213; Kraemer 1991:257).

\section{Conclusion}

In this article, I have traced the orthographic representation of the definite article in written JA folk tales and letters from pre-modern Egypt to medievalera Al-Andalus in an effort to resolve the question of why the definite article is written as a separate entity in post-seventeenth-century Egyptian JA texts. In the course of this exploration, I have demonstrated that medieval-era manifestations of this orthographic phenomenon may be viewed as the result of JA's contact with Romance, or at least, as a result of pre-tenth-century Romance-JA language contact, the consequences of which were retained as a stylistic feature in post-tenth-century JA writings. By tracing the representation of the definite article in medieval JA texts written by (i) Andalusī and Sicilian, (ii) Mag̉ribī, (iii) Alexandrian, and (iv) Egyptian, Palestinian, and Iraqi Jews, I have shown that this orthographic feature was limited predominantly to Jews of Andalusī, Sicilian, and Mag̈ribī origins during this period. It was not until after

38 The Sephardī Jews who fled to the Magrib, Egypt, and Palestine were generally considered to be more erudite and socially and economically well-off than the Jews living in Arab lands prior to $1492 \mathrm{CE}$ (Heath 2002:10). This social prestige may have contributed to the assimilation of some of their customs and practices, including in the realm of writing. These manuscripts may be found on the Friedberg Genizah Project website under the classmarks listed here. 
the expulsion of Jews from the Iberian Peninsula that the feature also became widespread in Egyptian JA writings. In this later period, the feature arose from analogy with the writing of the m.sg. definite article in Js.

These findings attest to the significant role orthography may play in disentangling the historical circumstances of language contact, and they challenge and develop the widespread understanding of late written JA as predominantly 'Hebraized.'

\section{References}

Ackerman-Lieberman, Philip. 2014. "The Disappearance of the Early Phonetic Judeo-Arabic Spelling and Sa'adya Gaon's Translation of the Bible." Jerusalem Studies in Arabic and Islam 41: 137-172.

Adams, James N. 2013. Social Variation and the Latin Language. Cambridge: Cambridge University Press.

Arad, Dotan \& Esther-Miriam Wagner. Wisdom and Greatness in One Place: The 15th c. Alexandrian Trader Moses ben Judah and his Circle. Leiden: Brill (forthcoming).

Ashur, Amir \& Tamar Zewi, 2019. "A Genizah Fragment of Saadya Gaon's Bible Translation Copied by Mevōrākh b. Nāthān in the 12th Century." Estudios del Oriente Próximo y el Mediterráneo 2: 113-120.

Avishur, Yitzhak. 1986. Tales of Women: The Folk Tales of the Jews of Iraq. Or Yehudah, Israel: Iraqi Jews Traditional Culture Centre (in Hebrew).

Bareket, Elinoar. 1999. Fustat on the Nile: The Jewish Elite in Medieval Egypt. Leiden: Brill. Barletta, Vincent. 2012. "Kharja." In The Princeton Encyclopedia of Poetry and Poetics: Fourth Edition, eds. Roland Greene et al. Princeton: Princeton University Press, 769-770.

Beinart, Haim. 2002. The Expulsion of the Jews from Spain. Oxford: The Littman Library of Jewish Civilisation.

Benaim, Annette. 2012. Sixteenth-Century Judeo-Spanish Testimonies: An Edition of Eighty-Four Testimonies from the Sephardic Responsa in the Ottoman Empire. Leiden: Brill.

Bennison, Amira K. \& Maria Angeles Gallego. 2010. "Religious Minorities under the Almohads: An Introduction." Journal of Medieval Iberian Studies 2.2: 143-154.

Ben-Sasson, Haim Hillel. 1976. A History of the Jewish People. Cambridge, MA: Harvard University Press.

Blau, Joshua. [1961] 1980. A Grammar of Medieval Judaeo-Arabic. Jerusalem: The Magnes Press (in Hebrew).

Blau, Joshua \& Simon Hopkins. 1984. "On Early Judaeo-Arabic Orthography." Zeitschrift für arabische Linguistik 12: 9-27. 
Blau, Joshua \& Simon Hopkins. 1987. "Judaeo-Arabic Papyri: Collected, Edited, Translated, and Analysed." Jerusalem Studies in Arabic and Islam 9: 87-160.

Bunis, David M. 2011. "Judezmo: The Jewish Language of the Ottoman Sephardim." European Judaism 44.1: 22-35.

Bunis, David M. 2016. “Judezmo (Ladino).” In The Handbook of Jewish Languages, eds. Lily Kahn \& Aaron Rubin. Leiden: Brill, 366-451.

Burnett, Charles. 2008. Ibn Baklarish's Book of Simples: Medical Remedies between Three Faiths in Twelfth-Century Spain. London: The Arcadian Library in association with Oxford University Press.

Clackson, James. 2016. "Latin as a Source for the Romance Languages." In The Oxford Guide to the Romance Languages, eds. Adam Ledgeway \& Martin Maiden. Oxford: Oxford University Press, 3-13.

Cohen, Mark R. 1980.Jewish Self-Government in Medieval Egypt: The Origins of the Office of Head of the Jews, ca. 1065-1126. Princeton, NJ: Princeton University Press.

Connolly, Magdalen M. 2018. Linguistic Variation in Egyptian Judaeo-Arabic Folk Tales and Letters from the Ottoman Period. PhD. Thesis, University of Cambridge.

Connolly, Magdalen M. 2020. “The Tale of the Cairene and the Countryman': A Late Judaeo-Arabic Narrative Revisited." Journal of Arabic and Islamic Studies (online pre-print: https://journals.uio.no/JAIS/article/view/7948).

Corriente, Federico. 2006. "Andalusi Arabic." In Encyclopedia of Arabic Language and Linguistics, eds. Kees Versteegh et al. Leiden: Brill, I, 101-111.

Fischer, Wolfdietrich. 2002. A Grammar of Classical Arabic. New Haven: Yale University Press.

Frank-Job, Barbara \& Maria Selig. 2016. "Early Evidence and Sources." In The Oxford Guide to the Romance Languages, eds. Adam Ledgeway \& Martin Maiden. Oxford: Oxford University Press, 24-34.

Gacek, Adam. 2012. Arabic Manuscripts. A Vademecum for Readers. Leiden: Brill.

Gallego, Maria Ángeles. 2003. "The Languages of Medieval Iberia and Their Religious Dimension." Medieval Encounters 9.1: 107-139.

Gil, Moshe. 1992. A History of Palestine, 634-1099. Cambridge: Cambridge University Press.

Gil, Moshe. 1997. In the Kingdom of Ishmael: Texts from the Cairo Genizah. Jerusalem: Mosad Byalik (in Hebrew).

Gil, Moshe. 2003. "The Jewish Merchants in the Light of Eleventh-Century Geniza Documents." Journal of the Economic and Social History of the Orient 46.3: 273-319.

Goldberg, Jessica L. 2012. Trade and Institutions in the Medieval Mediterranean: The Geniza Merchants and Their Business World. Cambridge: Cambridge University Press.

Giusti, Giuliana. 2016. "The Structure of the Nominal Group." In The Oxford Guide to the Romance Languages, eds. Adam Ledgeway \& Martin Maiden. Oxford: Oxford University Press, 541-555. 
Gutwirth, Eleazer. 1986. "The Family in Judeo-Spanish Genizah Letters of Cairo (XVIthXVIIIth C)." Vierteljahrschrift für Sozial- und Wirtschaftsgeschichte 73.2: 210-215.

Gutwirth, Eleazer. 1990-1993. "A Judeo-Spanish endecha from the Cairo Genizah." Mediterranean Language Review 6-7: 113-120.

Hary, Benjamin H. 1992. Multiglossia in Judaeo-Arabic. Leiden: Brill.

Hary, Benjamin H. 1996. "Adaptations of Hebrew Script.” In The World's Writing Systems, eds. Peter T. Daniels \& William Bright. Oxford: Oxford University Press, 727-734.

Hary, Benjamin H. 1997. "The Impact of the Cairo Genizah Documents on the Study of the History of Arabic." Bulletin of the Israeli Academic Center in Cairo 21: 35-40.

Hary, Benjamin H. 20o9. Translating Religion: Linguistic Analysis of Judaeo-Arabic Sacred Texts from Egypt. Leiden: Brill.

Heath, Jeffrey. 2002.Jewish and Muslim Dialects of Moroccan Arabic. London: Curzon.

Herman, József. 1996. "The End of the History of Latin." Romance Philology 49.4: $364-382$.

Heselwood, Barry \& Janet C. E. Watson. 2013. "The Arabic Definite Article Does Not Assimilate." LWPLP 18: 34-53.

Khan, Geoffrey. 1992. "Notes on the Grammar of a Late Judaeo-Arabic Text." Jerusalem Studies in Arabic and Islam 15: 220-239.

Khan, Geoffrey. 20o6. "A Judaeo-Arabic Commercial Letter from Early NineteenthCentury Egypt." Ginzei Qedem 2: 37-58.

Khan, Geoffrey. 2007. "Judaeo-Arabic." In Encyclopedia of Arabic Language and Linguistics, eds. Kees Versteegh et al. Leiden: Brill, II, 526-536.

Khan, Geoffrey. 2008. "The Syriac Words in the Kitāb al-Mustain̄i in the Arcadian Library Manuscript." In Ibn Baklarish's Book of Simples: Medical Remedies Between Three Faiths in Twelfth-Century Spain, ed. Charles Burnett. London: The Arcadian Library in association with Oxford University Press, 95-104.

Khan, Geoffrey. 2010. "Vocalized Judaeo-Arabic manuscripts in the Cairo Genizah.” In From a Sacred Source: Genizah Studies in Honour of Professor Stefan C. Reif, eds. Ben Outhwaite \& Siam Bhayro. Leiden: Brill, 201-217.

Khan, Geoffrey. 2016. "Judaeo-Arabic." In The Handbook of Jewish Languages, eds. Lily Kahn \& Aaron Rubin. Leiden: Brill, 22-63.

Khan, Geoffrey. 2018. “Judaeo-Arabic." In Arabic Historical Dialectology: Linguistic and Sociolinguistic Approaches, ed. Clive Holes. Oxford: Oxford University Press, 148-169. Kossmann, Maartin. 2013. Arabic Influence on Northern Berber. Leiden: Brill.

Kraemer, Joel L. 1991. "Spanish Ladies from the Cairo Geniza." Mediterranean Historical Review 6.2: 237-267.

Ledgeway, Adam. 2012. From Latin to Romance: Morphosyntactic Typology and Change. Oxford: Oxford University Press.

Ledgeway, Adam. 2016. "Functional Categories." In The Oxford Guide to the Romance Languages, eds. Adam Ledgeway \& Martin Maiden. Oxford: Oxford University Press, $761-771$. 
López-Morillas, Consuelo. 200o. “Language.” In The Literature of Al-Andalus, eds. María Rosa Menocal et al. Cambridge: Cambridge University Press, 33-59.

Minervini, Laura. 1992. Testi guideospagnoli medievali (Castiglia e Aragone). Naples: Liguori (in Italian).

Penny, Ralph. 200o. "Variation in Judeo-Spanish." In Variation and Change in Spanish, ed. Ralph Penny. Cambridge: Cambridge University Press, 174-193.

Ramat, Paolo \& Davide Ricca. 2016. "Romance: A Typological Approach." In The Oxford Guide to the Romance Languages, eds. Adam Ledgeway \& Martin Maiden. Oxford: Oxford University Press, 50-62.

Rosen, Tova. 2000. "The Muwashshah." In The Literature of Al-Andalus, eds. María Rosa Menocal et al. Cambridge: Cambridge University Press, 163-189.

Rustow, Marina. 2008. Heresy and the Politics of Community: The Jews of the Fatimid Caliphate. Ithaca: Cornell University Press.

Schippers, Arie. 2002. "A Muwashshah from the Genizah." Zutot 2.1: 56-64.

Schwarzwald, Ora (Rodrigue). 2004. "Judaeo-Spanish Studies." In The Oxford Handbook of Jewish Studies, ed. Martin Goodman. Oxford: Oxford University Press, 572-6oo.

Simonsohn, Shlomo. 1997. The Jews in Sicily:383-1300. Leiden: Brill.

Stillman, Norman A. 1973. "The Eleventh-Century Merchant House of Ibn 'Awkal: A Geniza Study." Journal of the Economic and Social History of the Orient 16.1: 1-87.

Villaverde Amieva, Juan Carlos. 2008. "Towards a Study of the Romance Languages in the Kitāb al-Musta 'in̄i." In Ibn Baklarish's Book of Simples: Medical Remedies Between Three Faiths in Twelfth-Century Spain, ed. Charles Burnett. London: The Arcadian Library in association with Oxford University Press, 43-74.

Wagner, Esther-Miriam. 2010. Linguistic Variety of Judaeo-Arabic in Letters from the Cairo Genizah. Leiden: Brill.

Wasserstein, David J. 1991. "The Language Situation in al-Andalus." In Studies on the Muwashshah and the Kharja: Proceedings of the Exeter International Colloquium, eds., Alan Jones \& Richard Hitchcock. Reading: Ithaca Press, 1-15.

Wright, Roger. 1976. "Speaking, Reading and Writing Late Latin and Early Romance." Neophilologus 6o.2: 178-189.

Wright, Roger. "Latin and Romance in the Medieval Period: A Sociophilological Approach." In The Oxford Guide to the Romance Languages, eds. Adam Ledgeway \& Martin Maiden. Oxford: Oxford University Press, 14-23.

Zemánek, Petr. 2006. “Assimilation." In Encyclopedia of Arabic Language and Linguistics, eds. Kees Versteegh et al. Leiden: Brill, I, 204-206.

Zwarjtes, Otto. 2006. "Andalus." In Encyclopedia of Arabic Language and Linguistics, eds. Kees Versteegh et al. Leiden: Brill, I, 96-101. 


\section{Appendix (Tables 1-4)}

TABLE 1 Representation of the definite article in Andalusī and Sicilian Jewish writers' documents

Name \& place of Classmark

Date Separated definite

birth (if known)

(if known) article (yes/no)

1 (Abū Ya'qūb) JTS ENA 2805.24

ca. $1050 \mathrm{CE}$ Yes

Isḥāq b. Yūsuf

al-Andalusī

2 Ismaīl b. Ishāq

CUL T-S $10 \mathrm{~J} 5.12$

ca. $1065 \mathrm{CE} \quad$ Yes

al-Andalusī, b.

CUL T-S 8J25.6

Toledo ${ }^{40}$

CUL T-S $13 \mathrm{~J} 23.22$

CUL T-S 13J28.11

Bodl. MS

Heb.d.75/20

3 Ibrahīm b. Isḥāq AIU VII E.4

al-Andalusī

CUL T-S 1OJ16.10

4 Yahūda b. Isma‘ìl

CUL T-S 1OJ5.24

al-Andalusī

CUL T-S Misc.28.37

Tendency towards

separation

(Two different

hands)

5 Yacqūb b. Ismāinl CUL T-S 16.7

al-Andalusī

CUL T-S 8J41.2

ca. $105 \mathrm{OCE}$

CUL T-S 16.7

CUL T-S 20.76

106o CE

CUL T-S 8J41.2 are

written in the same

(Goldberg 2012:131)

CUL T-S 1OJ2O.10

hand (with separation);

addresses of CUL T-S

16.7, CUL T-S 8J41.2, and CUL T-S 20.76 are

written in the same

hand, but the main

texts of CUL T-S 20.76

and CUL T-S $10 \mathrm{~J} 20.10$

are in a different hand,

and the definite article

is attached to the noun

in these two letters.

$40 \quad$ (Goldberg 2012:318-319.) 
TABLE 1 Representation of the definite article in Andalusī and Sicilian Jewish (cont.)

\begin{tabular}{|c|c|c|c|c|}
\hline & $\begin{array}{l}\text { Name \& place of } \\
\text { birth (if known) }\end{array}$ & Classmark & $\begin{array}{l}\text { Date } \\
\text { (if known) }\end{array}$ & $\begin{array}{l}\text { Separated definite } \\
\text { article (yes/no) }\end{array}$ \\
\hline 6 & $\begin{array}{l}\text { Isma'îl b. Ya‘qūb } \\
\text { al-Andalusī }\end{array}$ & CUL T-S 20.127 & $1064 \mathrm{CE}$ & $\begin{array}{l}\text { Slight tendency } \\
\text { towards separation, but } \\
\text { generally attached. }\end{array}$ \\
\hline 7 & $\begin{array}{l}\text { Yacqūb b. Ismacīl } \\
\text { al-Andalusī }\end{array}$ & CUL T-S Misc 28.199 & & Yes \\
\hline 8 & $\begin{array}{l}\text { Mevorak b. } \\
\text { Isrā'īl b. Ğanūnī, } \\
\text { Palermo }\end{array}$ & CUL T-S $10 \mathrm{~J} 10.25$ & $105^{2} \mathrm{CE}$ & Yes \\
\hline 9 & $\begin{array}{l}\text { Ibrahīm b. Yiṣhạaq } \\
\text { b. al-Zūlāfī }\end{array}$ & CUL T-S $13 \mathrm{~J} 28.1$ & & Yes \\
\hline 10 & 'Ațā b. Zakarī & CUL T-S 12.371 & & $\begin{array}{l}\text { Slight tendency } \\
\text { towards separation, but } \\
\text { generally attached. }\end{array}$ \\
\hline 11 & $\begin{array}{l}\text { Hayyim b. } \\
\text { 'Ammār Madīn̄̄ }\end{array}$ & $\begin{array}{l}\text { CUL T-S } 20.122 \\
\text { JTS ENA NS } 2.30\end{array}$ & ca. $1055 \mathrm{CE}$ & $\begin{array}{l}\text { Tendency towards } \\
\text { separation, most } \\
\text { noticeable when } \\
\text { definite article } \\
\text { is preceded by a } \\
\text { bound-morpheme } \\
\text { preposition. }\end{array}$ \\
\hline 12 & $\begin{array}{l}\text { Zakarī b. 'Ammār } \\
\text { Madīnī }\end{array}$ & CUL T-S $16.13^{41}$ & ca. $1069 \mathrm{CE}$ & $\begin{array}{l}\text { Tendency towards } \\
\text { separation, but } \\
\text { generally attached. }\end{array}$ \\
\hline 13 & $\begin{array}{l}\text { Da'ūd b. 'Ammār } \\
\text { Madīnī }\end{array}$ & $\begin{array}{l}\text { CUL T-S 8J26.15 } \\
\text { JTS ENA 2805.18 } \\
\text { Bodl. Heb.d.68/108 } \\
\text { (Possibly two } \\
\text { different hands) }\end{array}$ & ca. $1065 \mathrm{CE}$ & $\begin{array}{l}\text { Yes } \\
\text { No } \\
\text { Yes }\end{array}$ \\
\hline 14 & Yahūda ha-Levi & $\begin{array}{l}\text { CUL T-S 8J18.5 } \\
\text { CUL T-S } 10 \mathrm{~J} 15.1 \\
\text { CUL T-S } 13 \mathrm{~J} 17.22\end{array}$ & 12th century & Yes \\
\hline
\end{tabular}

41 Gil (1997) attributes this letter to Ḥayyim b. 'Ammār, while Ben-Sasson (1976) ascribes it to Zakarī b. 'Ammār. It is certainly written in a different hand to that associated with Ḥayyim b. 'Ammār (see, for example, CUL T-S 20.122). 
TABLE 1 Representation of the definite article in Andalusī and Sicilian Jewish (cont.)

\begin{tabular}{|c|c|c|c|c|}
\hline & $\begin{array}{l}\text { Name \& place of } \\
\text { birth (if known) }\end{array}$ & Classmark & $\begin{array}{l}\text { Date } \\
\text { (if known) }\end{array}$ & $\begin{array}{l}\text { Separated definite } \\
\text { article (yes/no) }\end{array}$ \\
\hline 15 & $\begin{array}{l}\text { Mūsā b. Yūsuf } \\
\text { Yijū }\end{array}$ & $\begin{array}{l}\text { CUL T-S 13J20.7 } \\
\text { CUL T-S } 10 J 14.16\end{array}$ & ca. $1155 \mathrm{CE}$ & $\begin{array}{l}\text { Yes } \\
\text { Yes }\end{array}$ \\
\hline 16 & $\begin{array}{l}\text { Peraḥya b. Yūsuf } \\
\text { b. Yijū } 42\end{array}$ & $\begin{array}{l}\text { CUL T-S 8J36.3 } \\
\text { CUL T-S 8J16.10 } \\
\text { CUL T-S 8J20.25 } \\
\text { CUL T-S 8J17.20 } \\
\text { CUL T-S 8J23.2 }\end{array}$ & ca. $1154 \mathrm{CE}$ & Yes \\
\hline 17 & $\begin{array}{l}\text { Yūsuf b. Perahyaa } \\
\text { b. Yijū }\end{array}$ & CUL T-S 13J6.15 & ca. $1154 \mathrm{CE}$ & Yes \\
\hline 18 & $\begin{array}{l}\text { Samuel b. Yūsuf } \\
\text { Yijū }\end{array}$ & $\begin{array}{l}\text { Bodl. Ms Heb. b. } \\
11 / 15\end{array}$ & & Yes \\
\hline 19 & Mūsā b. Maimon & $\begin{array}{l}\text { CUL T-S Ka4.1 } \\
\text { CUL T-S } 16.290 \\
\text { CUL T-S Ar.21.112 }\end{array}$ & & Yes \\
\hline 20 & Mūsā ha-Sefardī & CUL T-S 8J41.7 & & $\begin{array}{l}\text { Yes, but sometimes } \\
\text { attached. }\end{array}$ \\
\hline 21 & $\begin{array}{l}\text { Yūsuf b. Šešet } \\
\text { ha-Sefardi }\end{array}$ & $\begin{array}{l}\text { CUL T-S Misc. } 37 \cdot 5 \\
\text { recto }\end{array}$ & & $\begin{array}{l}\text { Yes (first two lines in } \\
\text { JA) }\end{array}$ \\
\hline 22 & $\begin{array}{l}\text { Samhụūn d. Da’ūd } \\
\text { b. al-Siqillī }\end{array}$ & Budapest DK 327 & & Yes \\
\hline 23 & $\begin{array}{l}\text { Kallūf b. Mūsā b. } \\
\text { al-Ṣā'ī' al-Barqī } \\
\text { (lived in Palermo, } \\
\text { but birthplace } \\
\text { unknown) }\end{array}$ & Bodl. ms Heb.a.3/13 & & No \\
\hline 24 & $\begin{array}{l}\text { Yahūda ha-Kohen } \\
\text { b. Yūsuf (Italy/ } \\
\text { Maġrib) }\end{array}$ & $\begin{array}{l}\text { CUL T-S } 16.235 \\
\text { CUL T-S } 16.150 \\
\text { CUL T-S } 12.657\end{array}$ & & No \\
\hline 25 & $\begin{array}{l}\text { Sicilian rental } \\
\text { deed }\end{array}$ & JTS ENA NS 16.27 & ca. $1136 \mathrm{CE}$ & Yes \\
\hline 42 & \multicolumn{4}{|c|}{$\begin{array}{l}\text { CUL T-S } 13 \mathrm{~J} 27.10 \text { is addressed from this sender but is in a different hand to the other } \\
\text { manuscripts. }\end{array}$} \\
\hline 43 & $\begin{array}{l}\text { Where exactly Yal } \\
\text { gests that he was } \\
\text { (CUL T-S Box G1. } \\
\text { 1980:105-107). Bar }\end{array}$ & $\begin{array}{l}\text { hūda ha-Kohen b. Yūsuf } \\
\text { of Palestinian descent, } \\
\text { 74) which suggest that } \\
\text { reket claims he was from }\end{array}$ & $\begin{array}{l}\text { hailed from rem } \\
\text { while Cohen cit } \\
\text { he was born an } \\
\text { the Magrib (199s }\end{array}$ & $\begin{array}{l}\text { ns uncertain - Goitein sug- } \\
\text { details from a manuscript } \\
\text { raised in Italy (see Cohen } \\
\text { o). }\end{array}$ \\
\hline
\end{tabular}


TABLE 1 Representation of the definite article in Andalusī and Sicilian Jewish (cont.)

\begin{tabular}{|c|c|c|c|c|}
\hline & $\begin{array}{l}\text { Name \& place of } \\
\text { birth (if known) }\end{array}$ & Classmark & $\begin{array}{l}\text { Date } \\
\text { (if known) }\end{array}$ & $\begin{array}{l}\text { Separated definite } \\
\text { article (yes/no) }\end{array}$ \\
\hline 26 & Legal document & $\begin{array}{l}\text { CUL T-S 8J8.17 } \\
\text { (recto) }\end{array}$ & & Yes \\
\hline 27 & $\begin{array}{l}\text { Letter of an } \\
\text { individual who } \\
\text { had moved from } \\
\text { Sicily to Tyre }\end{array}$ & CUL T-S $13 \mathrm{~J} 13.27$ & & Yes \\
\hline 28 & $\begin{array}{l}\text { Letter sent } \\
\text { from Sicily by a } \\
\text { mother to her } \\
\text { son }\end{array}$ & CUL T-S 8.9 & & Yes \\
\hline 29 & $\begin{array}{l}\text { Unidentified } \\
\text { sender }\end{array}$ & CUL T-S 12.218 & & Yes \\
\hline 30 & $\begin{array}{l}\text { Sicilian man to } \\
\text { his wife in Sicily }\end{array}$ & Moss. VII.162.3 & & Yes \\
\hline 31 & $\begin{array}{l}\text { Letter to Isma'īl } \\
\text { al-Andalusī } \\
\text { informing him } \\
\text { of his mother's } \\
\text { death }\end{array}$ & CUL T-S $13 \mathrm{~J} 22.1$ & & Yes \\
\hline
\end{tabular}

TABLE 2 Representation of the definite article in Mag̉ribī Jewish writers' documents.

\begin{tabular}{|c|c|c|c|c|}
\hline & $\begin{array}{l}\text { Name \& place of } \\
\text { birth (if known) }\end{array}$ & Classmark & $\begin{array}{l}\text { Date (if } \\
\text { known) }\end{array}$ & $\begin{array}{l}\text { Separated definite } \\
\text { article (yes/no) }\end{array}$ \\
\hline \multirow[t]{2}{*}{32} & (Abū Isḥaq) & Bodl. Ms Heb.d.66/93 & 11 th century & Yes \\
\hline & $\begin{array}{l}\text { Ibrahīm b. 'Ațā }{ }^{44} \\
\text { (a.k.a. Abraham b. } \\
\text { Natan) }\end{array}$ & $\begin{array}{l}\text { CUL T-S 10J9.26 } \\
\text { (Possibly two different } \\
\text { hands) }\end{array}$ & $\mathrm{CE}$ & Yes \\
\hline
\end{tabular}

44 Identified as a Tunisian court physician in Cohen (1980:30). Bodl. Ms Heb.d.66/93 is written from one Abraham b. Natan in a different hand to that found in CUL T-S 10J9.26. In Bodl. Ms Heb.d.66/93, the definite article is written as a separate entity. 
TABLE 2 Representation of the definite article in Mag̉ribī Jewish writers' documents (cont.)

\begin{tabular}{|c|c|c|c|c|}
\hline & $\begin{array}{l}\text { Name \& place of } \\
\text { birth (if known) }\end{array}$ & Classmark & $\begin{array}{l}\text { Date (if } \\
\text { known) }\end{array}$ & $\begin{array}{l}\text { Separated definite } \\
\text { article (yes/no) }\end{array}$ \\
\hline 33 & $\begin{array}{l}\text { Yūsuf and Nissīm } \\
\text { b. Berekyā }\end{array}$ & $\begin{array}{l}\text { Bodl. Ms Heb.d.65/9 } \\
\text { CUL T-S } 16.64 \\
\text { CUL T-S 13J36.1 } \\
\text { CUL T-S 8J28.9 }\end{array}$ & $\begin{array}{l}1015 \mathrm{CE} \\
1020 \mathrm{CE}\end{array}$ & $\begin{array}{l}\text { Yes; CUL T-S } 10 J 9.26 \text {, } \\
\text { Bodl. Ms Heb.d.65/9, } \\
\text { CUL T-S } 16.64 \text {, CUL } \\
\text { T-S 13J36.1 and CUL } \\
\text { T-S 8J28.9 are all } \\
\text { written by the same } \\
\text { scribe }\end{array}$ \\
\hline 34 & $\begin{array}{l}\text { Šelomo b. Yahūda } \\
\text { (al-Fāsī) }\end{array}$ & $\begin{array}{l}\text { CUL T-S } 13 \mathrm{~J} 36.5 \\
\text { CUL T-S } 16.275 \text { verso } \\
\text { Moss. Ia.20.1 } \\
\text { Moss. Ia.20.2 } \\
\text { CUL T-S Ns J14 } \\
\text { Bodl. Heb.a.3/3 } \\
\text { Bodl. Heb.c. } 28 / 44 \\
\text { Bodl. Heb.c. } 28 / 67\end{array}$ & $\begin{array}{l}1028 \mathrm{CE} \\
1029 \mathrm{CE} \\
1033 \mathrm{CE}\end{array}$ & Yes \\
\hline 35 & $\begin{array}{l}\text { Nahray b. Nissīm } \\
\text { al-Mag̉ribī (see } \\
\text { CUL T-S 8J19.11) }\end{array}$ & $\begin{array}{l}\text { Moss. IV.80 } \\
\text { Moss. II.188.2 } \\
\text { CUL T-S 8J29.11 } \\
\text { L-G Misc.10o } \\
\text { Bodl. Ms Heb.c.28/33 } \\
\text { Bodl. Ms Heb.d.66/41 } \\
\text { CUL T-S 13J19.27 } \\
\text { CUL T-S 8J22.10 } \\
\text { CUL T-S 1OJ12.26 }\end{array}$ & $\begin{array}{l}\text { ca. } 1053 \mathrm{CE} \\
\text { ca. } 1055 \mathrm{CE} \\
1053 \mathrm{CE} \\
\text { ca. } 1050 \mathrm{CE} \\
\text { ca. } 1045 \mathrm{CE}\end{array}$ & No \\
\hline 36 & $\begin{array}{l}\text { (Abū l-Farağ) } \\
\text { Nissīm b. Nahray } \\
\text { b. Nissīm }\end{array}$ & $\begin{array}{l}\text { Bodl. Ms heb.d.66/46 } \\
\text { CUL T-S Ar. } 48.42 \\
\text { (two different hands) }\end{array}$ & & $\begin{array}{l}\text { No } \\
\text { Inconsistent }\end{array}$ \\
\hline
\end{tabular}


TABLE 2 Representation of the definite article in Maġibī Jewish writers' documents (cont.)

\begin{tabular}{|c|c|c|c|c|}
\hline & $\begin{array}{l}\text { Name \& place of } \\
\text { birth (if known) }\end{array}$ & Classmark & $\begin{array}{l}\text { Date (if } \\
\text { known) }\end{array}$ & $\begin{array}{l}\text { Separated definite } \\
\text { article (yes/no) }\end{array}$ \\
\hline 37 & $\begin{array}{l}\text { Natan b. Nahray } \\
\text { (b. Natan) }\end{array}$ & $\begin{array}{l}\text { Moss. IV.18 } \\
\text { CUL T-S } 8.17 \text { (recto) } \\
\text { CUL T-S 10J14.26 } \\
\text { CUL T-S 8J27.5 } \\
\text { CUL T-S 10J16.17 } \\
\text { CUL T-S 10J16.18 } \\
\text { CUL T-S 10J20.17 } \\
\text { CUL T-S 10J20.18 } \\
\text { CUL T-S NS J187 } \\
\text { BL Or.5566.D.3 } \\
\text { Bodl. MS Heb.d.66/79 } \\
\text { Bodl. Ms Heb.d.66/91 } \\
\text { CUL T-S 12.610 } \\
\text { CUL T-S 8J26.17 }\end{array}$ & $\begin{array}{l}1064 \mathrm{CE} \\
\text { ca. } 1061 \mathrm{CE} \\
\text { ca. } 1065 \mathrm{CE} \\
\text { ca. } 1062 \mathrm{CE} \\
\text { ca. } 1062 \mathrm{CE} \\
\text { ca. } 1062 \mathrm{CE} \\
\text { ca. } 1063 \mathrm{CE} \\
\text { ca. } 1063 \mathrm{CE}\end{array}$ & $\begin{array}{l}\text { Tendency towards } \\
\text { separation, but } \\
\text { inconsistent }\end{array}$ \\
\hline 38 & $\begin{array}{l}\text { Benāyā b. Mūsā } \\
\text { l-Mag̉ribī }\end{array}$ & $\begin{array}{l}\text { CUL T-S 8J17.32 } \\
\text { CUL T-S } 10 \mathrm{~J} 19.10 \\
\text { CUL T-S } 13 \mathrm{~J} 23.3 \\
\text { Bodl. MS Heb.c.28/5O } \\
\text { CUL T-S } 10 \mathrm{~J} 6.2\end{array}$ & 1080 CE & $\begin{array}{l}\text { Yes; most evident in } \\
\text { CUL T-S } 13 \mathrm{~J} 23.3 \text { and } \\
\text { CUL T-S 10J19.10; } \\
\text { CUL T-S 10J6.2 is in a } \\
\text { different hand (with } \\
\text { some separation) }\end{array}$ \\
\hline 39 & $\begin{array}{l}\text { (Abū Zikri) } \\
\text { Yahūda b. Mūsā b. } \\
\text { Sig̀mār, Tunisia }^{45}\end{array}$ & $\begin{array}{l}\text { Moss. II.191 } \\
\text { CUL T-S 8J24.5 }\end{array}$ & & Yes \\
\hline 40 & $\begin{array}{l}\text { (Abū l-Hasan) } \\
\text { Labrāṭ b. Mūsā b. } \\
\text { Sig̀mār, Tunisia }\end{array}$ & $\begin{array}{l}\text { CUL T-S AS } 151.10 \\
\text { Bodl. MS Heb.b.13/49 } \\
\text { Moss. II. } 133 \\
\text { CUL T-S } 16.179 \\
\text { JTS ENA NS } 18.35\end{array}$ & $1056 \mathrm{CE}$ & Inconsistent \\
\hline 41 & $\begin{array}{l}\text { Mūsā b. Labrāṭ b. } \\
\text { Sig̀mār }\end{array}$ & CUL T-S 16.262 & $1100 \mathrm{CE}$ & No \\
\hline
\end{tabular}

45 Yahūda b. Mūsā b. Sig̀mār studied under Yahūda ha-kohen b. Yūsuf (see cul T-S 16.179) (Cohen 1980:116). 
TABLE 2 Representation of the definite article in Magiribī Jewish writers' documents (cont.)

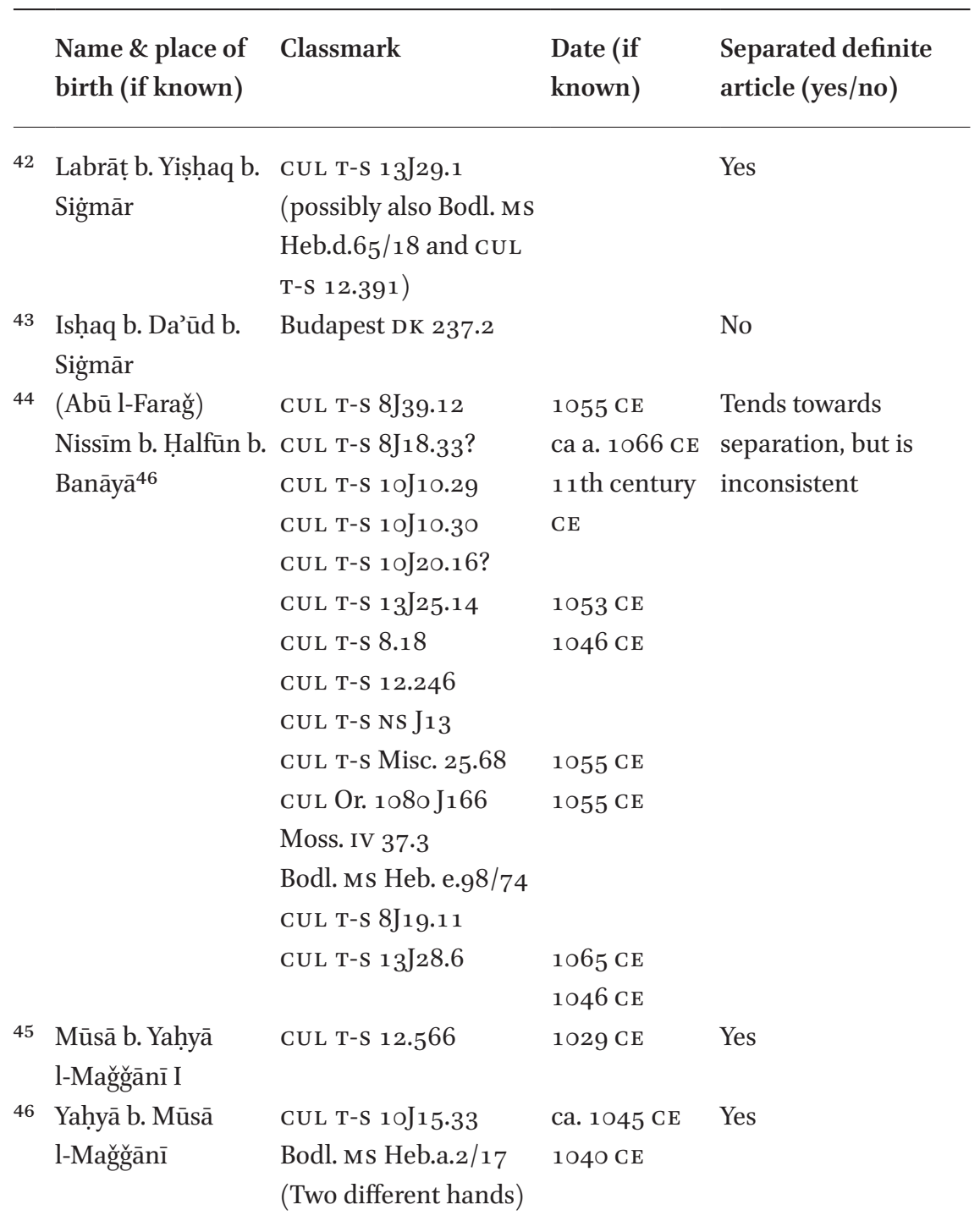

46 Nissīm b. Halfūn has previously been categorized as an Egyptian merchant (see Wagner 2010:17-18). However, in CUL T-S 10J6.2, a letter from Banāyā b. Mūsā, he is clearly addressed as 'Nissīm b. Halfūn al-Mag̉ribī' (verso, line 2). It is possible that he was born and raised in the Magirib, before moving to Egypt, in much the same way as Nissim $b$. Nahray and (Abū Imrān) Mūsā b. Abī l-Ḥayy Kalīla (see n. 50). This is more in keeping with his close ties to, and frequent correspondence with, the Magiribì merchants of this era. 
TABLE 2 Representation of the definite article in Mag̉ribī Jewish writers' documents (cont.)

\begin{tabular}{|c|c|c|c|c|}
\hline & $\begin{array}{l}\text { Name \& place of } \\
\text { birth (if known) }\end{array}$ & Classmark & $\begin{array}{l}\text { Date (if } \\
\text { known) }\end{array}$ & $\begin{array}{l}\text { Separated definite } \\
\text { article (yes/no) }\end{array}$ \\
\hline 47 & $\begin{array}{l}\text { Mūsā b. Yahyyā } \\
\text { l-Mağǧānī II }\end{array}$ & CUL T-S 13J29.11 & & Yes \\
\hline 48 & $\begin{array}{l}\text { Iṣhạaq b. 'Alī } \\
\text { Mağǧāānì }\end{array}$ & CUL T-S 8J25.3 & $1039 \mathrm{CE}$ & Yes \\
\hline 49 & $\begin{array}{l}\text { Abūn b. } \\
\text { Șadaqa l-Mağribī }\end{array}$ & $\begin{array}{l}\text { CUL T-S 8J19.23 } \\
\text { CUL T-S 10J5.10 } \\
\text { CUL T-S } 8.257 \\
\text { CUL T-S 10J11.13 } \\
\text { CUL T-S 13J25.12 } \\
\text { CUL T-S Ar.18.(1).165 }\end{array}$ & $1064 \mathrm{CE}$ & Yes \\
\hline 50 & $\begin{array}{l}\text { ‘Ayyāš b. } \\
\text { Șadaqa l-Mağribī }\end{array}$ & $\begin{array}{l}\text { CUL T-S 8J36.4 } \\
\text { CUL T-S } 10 \mathrm{~J} 17.24 \\
\text { CUL T-S } 13 \mathrm{~J} 13.11^{47} \\
\text { CUL T-S NS J129 } \\
\text { CUL T-S AS } 145.16\end{array}$ & $1050 \mathrm{CE}$ & $\begin{array}{l}\text { Slight tendency } \\
\text { towards separation, } \\
\text { but generally attached }\end{array}$ \\
\hline 51 & Șadaqa b. 'Ayyāš & Bodl. ms Heb.d.66/15 & & $\begin{array}{l}\text { Slight tendency } \\
\text { towards separation, } \\
\text { but generally attached }\end{array}$ \\
\hline 52 & $\begin{array}{l}\text { Sahl b. Mavesser b. } \\
\text { Nahūm }\end{array}$ & $\begin{array}{l}\text { CUL T-S } 13 \mathrm{~J} 16.3 \\
\text { CUL T-S } 13 \mathrm{~J} 17.5 \\
\text { JTS ENA } 4020.59 \\
\text { JTS ENA } 2740.3 \\
\text { CUL T-S } 16.24\end{array}$ & & No \\
\hline 53 & Yahūda b. Sahl & $\begin{array}{l}\text { CUL T-S AS } 152.156 \\
\text { Moss. Ia.12.2 } \\
\text { CUL T-S 6J3.19 }\end{array}$ & ca. $1050 \mathrm{CE}$ & $\begin{array}{l}\text { Tendency towards } \\
\text { separation, } \\
\text { particularly when } \\
\text { preceded by a } \\
\text { bound morpheme } \\
\text { preposition; more } \\
\text { frequent separation in } \\
\text { CUL T-S 6J3.19 }\end{array}$ \\
\hline
\end{tabular}

47 See Goldberg (2012:58-62) for a translation and discussion of this letter's contents. 
TABLE 2 Representation of the definite article in Mag̉ribī Jewish writers' documents (cont.)

\begin{tabular}{|c|c|c|c|c|}
\hline & $\begin{array}{l}\text { Name \& place of } \\
\text { birth (if known) }\end{array}$ & Classmark & $\begin{array}{l}\text { Date (if } \\
\text { known) }\end{array}$ & $\begin{array}{l}\text { Separated definite } \\
\text { article (yes/no) }\end{array}$ \\
\hline 54 & $\begin{array}{l}\text { Yūsuf b. Sahl } \\
\text { al-Baradānīis }\end{array}$ & $\begin{array}{l}\text { CUL T-S } 10 \mathrm{~J} 15.5 \\
\text { Bodl. Ms Heb.c.28.20 }\end{array}$ & & Yes \\
\hline 55 & $\begin{array}{l}\text { Mūsā b. Ishạaq } \\
\text { al-Safāquṣī, } \\
\text { Tunisia }\end{array}$ & $\begin{array}{l}\text { CUL T-S } 13 J_{29.8} \\
\text { CUL T-S NS J563 }\end{array}$ & ca. $1059 \mathrm{CE}$ & $\begin{array}{l}\text { Slight tendency } \\
\text { towards separation, } \\
\text { but generally attached }\end{array}$ \\
\hline 56 & $\begin{array}{l}\text { Salāma b. Mūsā } \\
\text { al-Safāquṣ̄ī, } \\
\text { Tunisia }\end{array}$ & $\begin{array}{l}\text { CUL T-S } 10 \mathrm{~J} 4.2 \\
\text { Moss. IV.36.3 } \\
\text { Penn. Halper } 389\end{array}$ & $\begin{array}{l}\text { ca. } 1059 \mathrm{CE} \\
1064 \mathrm{CE}\end{array}$ & $\begin{array}{l}\text { Slight tendency } \\
\text { towards separation, } \\
\text { more noticeable in } \\
\text { Moss. IV.36.3 (e.g., see } \\
\text { lines } 6 \text { and 12) }\end{array}$ \\
\hline 57 & $\begin{array}{l}\text { Salāma b. Nissīm } \\
\text { b. Isḥaq al-Barqī }\end{array}$ & $\begin{array}{l}\text { CUL T-S } 13 \mathrm{~J} 27.18 \\
\text { CUL T-S } 8 \mathrm{~J} 22.8 \\
\text { CUL T-S } 12.793 \\
\text { Bodl. Ms Heb.c.28/36 }\end{array}$ & $\begin{array}{l}1053 \mathrm{CE} \\
\text { ca. } 1055 \mathrm{CE}\end{array}$ & $\begin{array}{l}\text { Separation more } \\
\text { noticeable in CUL T-S } \\
\text { 13J27.18 }\end{array}$ \\
\hline 58 & $\begin{array}{l}\text { Yahūda b. Yūsuf b. } \\
\text { Simḥa }\end{array}$ & CUL Or. $108 \circ$ J35 & & No \\
\hline 59 & $\begin{array}{l}\text { Yūsuf b. Yahūda b. } \\
\text { Simḥa }\end{array}$ & JTS ENA 3793.6 & & Yes \\
\hline 60 & $\begin{array}{l}\text { Isḥaq b. Simḥa } \\
\text { al- Naysābūrī }\end{array}$ & $\begin{array}{l}\text { CUL T-S } 8 \mathrm{~J} 13 \cdot 3 \\
\text { CUL T-S } 13 \mathrm{~J} 21.26 \\
\text { CUL T-S } 13 \mathrm{~J} 22 \cdot 30 \\
\text { CUL T-S Ar.18(1).51 } \\
\text { CUL T-S 18J4.6 } \\
\text { CUL T-S AS } 149 \cdot 12 \\
\text { Bodl. MS Heb.a.3/23 }\end{array}$ & $\begin{array}{l}\text { ca. } 11 \text { th- } \\
12 \text { th century } \\
\text { CE }\end{array}$ & Yes \\
\hline 61 & $\begin{array}{l}\text { Isma'īl b. Barhūn } \\
\text { al- Tīhertī }\end{array}$ & $\begin{array}{l}\text { CUL T-S } 8.265 \\
\text { CUL T-S } 10 J 11.23\end{array}$ & $\begin{array}{l}\text { Early } 11 \text { th } \\
\text { century CE }\end{array}$ & Yes \\
\hline 62 & $\begin{array}{l}\text { Ṣāliḥ b. Barhūn } \\
\text { al-Tīhertī }\end{array}$ & CUL T-S 13J29.6 & & Yes \\
\hline
\end{tabular}

48 Yūsuf b. Sahl al-Baradānī appears to be the great grandson of the Baghdadi cantor Joseph al-Baradani, whose son Nahūm emigrated to Qayrawan. Nahūm's son (Yannai/Sahl) and grandsons (Nahūm and Yūsuf) emigrated to Tyre, when the latter two had already reached maturity (see Gil 1992:186-187, n. 64). 
TABLE 2 Representation of the definite article in Mag̉ribī Jewish writers' documents (cont.)

\begin{tabular}{|c|c|c|c|c|}
\hline & $\begin{array}{l}\text { Name \& place of } \\
\text { birth (if known) }\end{array}$ & Classmark & $\begin{array}{l}\text { Date (if } \\
\text { known) }\end{array}$ & $\begin{array}{l}\text { Separated definite } \\
\text { article (yes/no) }\end{array}$ \\
\hline 63 & $\begin{array}{l}\text { Mūsā b. Barhūn } \\
\text { al-Tīhertī }\end{array}$ & $\begin{array}{l}\text { CUL T-S AS } 152.148 \\
\text { CUL T-S } 12.171 \\
\text { (different hand) }\end{array}$ & & $\begin{array}{l}\text { Yes. } \\
\text { CUL T-S } 12.171 \text { is } \\
\text { written in the same } \\
\text { hand as CUL T-S } \\
\text { 1oJ9.26, Bodl. MS } \\
\text { Heb.d.65/9, CUL } \\
\text { T-S } 16.64 \text {, CUL T-S } \\
\text { 13J36.1 and CUL T-S } \\
\text { 8J28.9 (see numbers } \\
32 \text { and } 33 \text { ). }\end{array}$ \\
\hline 64 & $\begin{array}{l}\text { Barhūn b. Isḥaq } \\
\text { al-Tīhertī }\end{array}$ & $\begin{array}{l}\text { CUL T-S 8J18.16 } \\
\text { CUL T-S } 20.180 \\
\text { CUL T-S 13J14.9 }\end{array}$ & $1045 \mathrm{CE}$ & $\begin{array}{l}\text { Tendency towards } \\
\text { separation, most } \\
\text { evident in CUL T-S } \\
20.18 \text { o and } 13 \mathrm{~J} 14.9\end{array}$ \\
\hline 65 & $\begin{array}{l}\text { Nissīm b. Isaac } \\
\text { al-Tīhertī }\end{array}$ & $\begin{array}{l}\text { CUL T-S } 10 \mathrm{~J} 19.9 \\
\text { CUL T-S } 13 \mathrm{~J} 8.13\end{array}$ & $1057 \mathrm{CE}$ & Yes \\
\hline 66 & $\begin{array}{l}\text { Barhūn b. Șālị̣ } \\
\text { al-Tīhertī }\end{array}$ & $\begin{array}{l}\text { CUL T-S 13J18.8 } \\
\text { CUL T-S 1OJ29.10 } \\
\text { CUL T-S 8J19.32 }\end{array}$ & $\begin{array}{l}1056 \mathrm{CE} \\
1050 \mathrm{CE}\end{array}$ & Yes \\
\hline 67 & $\begin{array}{l}\text { Barhūn b. Mūsā } \\
\text { l- Tīhertī }\end{array}$ & $\begin{array}{l}\text { CUL T-S AS } 147.136 \\
\text { CUL T-S 10J20.4 } \\
\text { Moss. IV.28.I } \\
\text { CUL T-S K2.32 } \\
\text { CUL T-S 13J20.19 } \\
\text { CUL T-S Misc.28.225 }\end{array}$ & 106o CE & Yes \\
\hline 68 & $\begin{array}{l}\text { Yūsuf b. Mūsā b. } \\
\text { Barhūn l- Tāhertī }\end{array}$ & $\begin{array}{l}\text { CUL T-S 8J24.10 } \\
\text { CUL T-S } 16.263 \\
\text { CUL T-S 8J25.11 } \\
\text { CUL T-S 8J16.31 } \\
\text { CUL T-S 20.71 } \\
\text { CUL T-S 8J19.1 } \\
\text { CUL T-S 13J8.5 } \\
\text { CUL T-S 13J25.9 } \\
\text { CUL T-S } 16.161 \\
\text { CUL T-S } 16.264 \\
\text { CUL T-S Ar.53.51 }\end{array}$ & $\begin{array}{l}1056 \mathrm{CE} \\
1061 \mathrm{CE} \\
1059 \mathrm{CE} \\
1062 \mathrm{CE}\end{array}$ & Yes \\
\hline
\end{tabular}


TABLE 2 Representation of the definite article in Maġibī Jewish writers' documents (cont.)

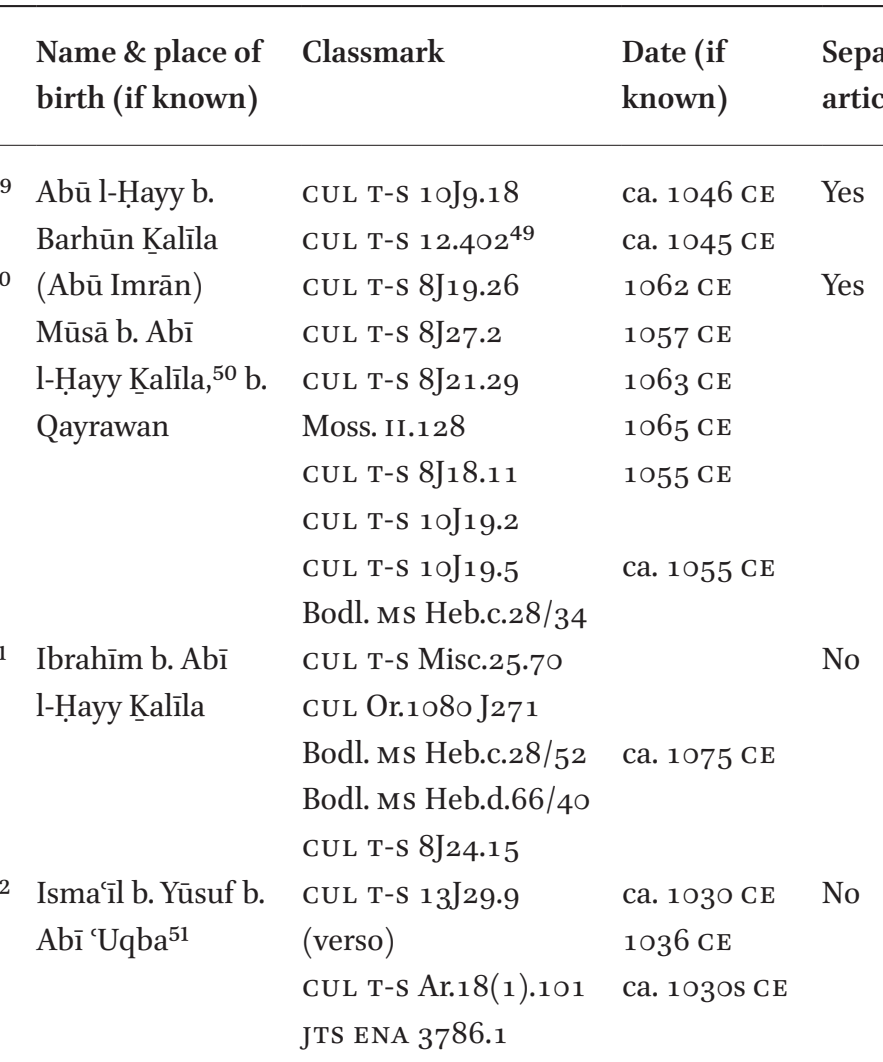

49 Gil (1997) attributed this letter to Mūsā b. Abī l-Ḥayy Knalīla, but it is written in Abū l-Ḥayy b. Barhūn Kalīla's hand.

50 (Abū Imrān) Mūsā b. Abī l-Ḥayy Kalīla was born in Qayrawan and emigrated to Alexandria as a young man. Alexandria remained his main residence until his death (Goldberg 2012:248).

51 A nephew of Yūsuf b. 'Awkal (Stillman 1973:25, 3o; Goldberg 2012:136). Yūsuf b. Yacqūb b. 'Awkal's (active in Genizah documents between 990 and $1030 \mathrm{CE}$ ) family hailed from Iraq (Rustow 2008:138) or Iran (Stillman 1973:17). The family moved to Tunisia during the midtenth century, remaining there until the late tenth century, when they settled in Egypt (ibid.; Stillman 1973:17). The family appear to have maintained ties with relations in Iraq throughout this period (Rustow 2008:138-139). Yūsuf b. Ya'qūb b. 'Awkal's date of birth is unknown, but it is likely that he was born before $970 \mathrm{CE}$ (on the basis that in $1008 \mathrm{CE}$ he is known to have had two adult sons (see Wagner 2010:17)). Stillman suggests that he was likely to have been educated in the Magirib (1973:17), before moving to Egypt and setting himself up as a merchant (in a fashion reminiscent of other Magiribī merchants' career trajectories, such as Nahray b. Nissīm, Nissīm b. Ḥalfūn (see n. 46), and Mūsā b. Abī l-Ḥayy Kalīla (see n. 50). 
TABLE 2 Representation of the definite article in Magiribī Jewish writers' documents (cont.)

\begin{tabular}{|c|c|c|c|c|}
\hline & $\begin{array}{l}\text { Name \& place of } \\
\text { birth (if known) }\end{array}$ & Classmark & $\begin{array}{l}\text { Date (if } \\
\text { known) }\end{array}$ & $\begin{array}{l}\text { Separated definite } \\
\text { article (yes/no) }\end{array}$ \\
\hline 73 & $\begin{array}{l}\text { Faraj, freed slave } \\
\text { of Taherti family }\end{array}$ & CUL T-S 8.12 & & $\begin{array}{l}\text { Slight tendency } \\
\text { towards separation, } \\
\text { but generally attached }\end{array}$ \\
\hline 74 & $\begin{array}{l}\text { Isrāōil b. Natan, b. } \\
\text { Qayrawan }\end{array}$ & $\begin{array}{l}\text { CUL T-S NS J388 } \\
\text { CUL T-S 1OJ10.24 } \\
\text { CUL T-S 6J5.8 } \\
\text { CUL T-S 13J14.18 } \\
\text { CUL T-S 13J16.4 } \\
\text { CUL T-S 13J16.7 } \\
\text { CUL T-S 13J26.4 } \\
\text { CUL T-S 13J29.7 } \\
\text { CUL T-S 8J19.9 } \\
\text { CUL T-S 10J15.6 } \\
\text { CUL T-S 10J15.12 } \\
\text { CUL T-S 10J15.19 } \\
\text { Bodl. MS Heb.a.2/18 } \\
\text { CUL T-S 12.362 }\end{array}$ & & $\begin{array}{l}\text { Often separated, but } \\
\text { occasionally attached }\end{array}$ \\
\hline 75 & $\begin{array}{l}\text { 'Amram b. Mūsā } \\
\text { l-Barqī, Libya }\end{array}$ & CUL T-S $10 \mathrm{~J} 11.2$ & $\begin{array}{l}\text { 11th century } \\
\mathrm{CE}\end{array}$ & $\begin{array}{l}\text { Slight tendency } \\
\text { towards separation, } \\
\text { but generally } \\
\text { attached. }\end{array}$ \\
\hline 76 & $\begin{array}{l}\text { Ibrahīm b. Ya'qūb } \\
{\text { al-Dar'i }{ }^{52}}^{{ }^{c}}\end{array}$ & CUL T-S 20.177 & ca. $1100 \mathrm{CE}$ & No \\
\hline 77 & $\begin{array}{l}\text { Hārūn b. Yūsuf } \\
\text { al-Ḡazzāl 'the } \\
\text { Spinner' }\end{array}$ & $\begin{array}{l}\text { CUL T-S } 13 \mathrm{~J} 29.2 \\
\text { CUL T-S NS J388 }\end{array}$ & $1027 \mathrm{CE}$ & Yes \\
\hline 78 & $\begin{array}{l}\text { Ismacīl b. Farah } \\
\text { al-Qābiṣī }\end{array}$ & $\begin{array}{l}\text { CUL T-S } 8.66 \\
\text { CUL T-S } 10 \mathrm{~J} 20.12 \\
\text { CUL T-S } 10 \mathrm{~J} 15.15 \\
\text { CUL T-S } 8 \mathrm{~J} 20.2 \\
\text { CUL T-S } 10 \mathrm{~J} 15.4 \\
\text { CUL T-S } 8.25 \\
\text { BL Or.5542.9 }\end{array}$ & $1056 \mathrm{CE}$ & Yes \\
\hline
\end{tabular}

52 Ibrahīm b. Yacqūb al-Dar'i is identified as being of North African descent by Cohen (1980:241). 
TABLE 2 Representation of the definite article in Maġribī Jewish writers' documents (cont.)

\begin{tabular}{|c|c|c|c|c|}
\hline & $\begin{array}{l}\text { Name \& place of } \\
\text { birth (if known) }\end{array}$ & Classmark & $\begin{array}{l}\text { Date (if } \\
\text { known) }\end{array}$ & $\begin{array}{l}\text { Separated definite } \\
\text { article (yes/no) }\end{array}$ \\
\hline 79 & $\begin{array}{l}\text { Yūsuf b. Farah } \\
\text { al-Q̄ābisī }\end{array}$ & $\begin{array}{l}\text { CUL T-S } 8.26 \\
\text { CUL T-S 8J20.6 } \\
\text { CUL T-S 8J2O.18 } \\
\text { JTS ENA } 1822 \text { A. } 67\end{array}$ & & Yes \\
\hline 80 & $\begin{array}{l}\text { Faraḥ b. Ismac̄il b. } \\
\text { Faraḥ al-Qābisī }\end{array}$ & $\begin{array}{l}\text { L-G Ar.1.31 } \\
\text { CUL T-S 13J19.9 } \\
\text { CUL T-S 18J3.13 } \\
\text { CUL T-S 8.255 } \\
\text { CUL T-S 8J19.4 } \\
\text { CUL T-S 8J21.2 } \\
\text { CUL T-S 8J21.7 } \\
\text { JTS ENA 4020.43 }\end{array}$ & $\begin{array}{l}1065 \mathrm{CE} \\
\text { ca. } 105 \mathrm{OS}\end{array}$ & $\begin{array}{l}\text { Tendency towards } \\
\text { separation, but often } \\
\text { attached }\end{array}$ \\
\hline 81 & $\begin{array}{l}\text { Faraḥ b. Yūsuf b. } \\
\text { Faraḥ al-Qābisī }\end{array}$ & $\begin{array}{l}\text { CUL T-S } 8.20 \\
\text { CUL T-S 8J26.5 } \\
\text { CUL T-S 8J27.13 } \\
\text { CUL T-S 10J14.17 } \\
\text { CUL T-S 13J28.2 } \\
\text { Bodl. MS Heb.d.76/59 }\end{array}$ & & $\begin{array}{l}\text { Inconsistent, but } \\
\text { tending towards } \\
\text { separation; several } \\
\text { different hands }\end{array}$ \\
\hline 82 & $\begin{array}{l}\text { Mūsā b. Isḥaq b. } \\
\text { Hisdā }^{53}\end{array}$ & $\begin{array}{l}\text { CUL T-S NS } 308.119 \\
\text { CUL T-S } 12.227 \\
\text { AIU VII.E.13O } \\
\text { Bodl. Ms Heb.c. } 27 / 82\end{array}$ & $\begin{array}{l}11 \text { th century } \\
\mathrm{CE}\end{array}$ & Yes \\
\hline 83 & Farah b. Ibrahīm & CUL T-S 12.367 & & Yes \\
\hline 84 & Daniel b. al-Šāma & $\begin{array}{l}\text { CUL T-S } 12.291 \text { (as } \\
\text { scribe for Ibrahīm b. } \\
\text { Yūsuf) }\end{array}$ & $\begin{array}{l}11 \text { th century } \\
\text { CE }\end{array}$ & Yes \\
\hline
\end{tabular}

53 Goldberg identifies Mūsā b. Isḥaq b. Ḥisdā as a nephew of Yūsuf b. Yacqūb b. 'Awkal (2012:287). Although Mūsā b. Isḥaq b. Ḥisdā is mentioned by Stillman (1973:70, n. 3), he does not make this familial connection. Wagner included Mūsā b. Isḥaq b. Ḥisdā’s letters in her Egyptian corpus (2010:19). 
TABLE 3 Representation of the definite article in merchants' letters, the writers of which lived in Alexandria

\begin{tabular}{|c|c|c|c|c|}
\hline & $\begin{array}{l}\text { Name \& place of } \\
\text { birth (if known) }\end{array}$ & Classmark & $\begin{array}{l}\text { Date (if } \\
\text { known) }\end{array}$ & $\begin{array}{l}\text { Separated definite } \\
\text { article (yes/no) }\end{array}$ \\
\hline 85 & $\begin{array}{l}\text { Efrayim b. Ismacīl } \\
\text { al-Ǧawharî̄ }^{-54}\end{array}$ & $\begin{array}{l}\text { CUL T-S 1OJ19.19 } \\
\text { CUL T-S 13J17.3 } \\
\text { CUL T-S 13J19.29 } \\
\text { Bodl. MS Heb. d.47/62 } \\
\text { BL Or.5563 C.19 }\end{array}$ & $\begin{array}{l}\text { ca. } 1030 \mathrm{CE} \\
1030 \mathrm{CE}\end{array}$ & $\begin{array}{l}\text { Tendency towards } \\
\text { separation in CUL } \\
\text { T-S } 10 J 19.19 \text { and } \\
\text { CUL T-S } 13 \mathrm{~J} 17 \cdot 3 \text {, } \\
\text { but much more } \\
\text { markedly separated } \\
\text { in Bodl. MS } \\
\text { Heb.d.47/62 }\end{array}$ \\
\hline 86 & $\begin{array}{l}\text { Ibrahīm b. Farah } \\
\text { al-Iskandarānī }\end{array}$ & $\begin{array}{l}\text { CUL T-S 8J18.10 } \\
\text { CUL T-S 8J18.13 } \\
\text { CUL T-S 10J11.9 } \\
\text { CUL T-S 10J19.3 } \\
\text { CUL T-S 10J31.8 } \\
\text { CUL T-S 13J15.9 } \\
\text { CUL T-S 13J17.15 } \\
\text { CUL T-S 13J26.8 } \\
\text { Moss. VII.153 } \\
\text { CUL T-S 12.524 } \\
\text { CUL T-S 8J20.17 (as scribe } \\
\text { for Mardūk b. Mūsa) } \\
\text { JTs ENA 2805.21 (as } \\
\text { scribe for Mardūk b. } \\
\text { Mūsa) }\end{array}$ & $\begin{array}{l}\text { ca. } 1055 \mathrm{CE} \\
1050 \mathrm{CE} \\
\text { ca. } 1056 \mathrm{CE} \\
\text { ca. } 1050 \mathrm{CE} \\
1045 \mathrm{CE} \\
1053 \mathrm{CE} \\
\text { ca. } 1050 \mathrm{CE} \\
1066 \mathrm{CE}\end{array}$ & Yes \\
\hline
\end{tabular}

54 Efrayim b. Ismaīl al-Ǧawharī is known to have lived and worked in Alexandria as an adult. However, there is scant information concerning his place of birth and upbringing. In one letter (CUL T-S 13J19.29) he refers to 'my (maternal) uncle' Mūsā in Qayrawan (see Stillman 1973:26; Goldberg 2012:188). This, when coupled with his close association with the Mag̉ribī merchants, suggests that he may not have been a native Egyptian (see Wagner 2010:18 who included Efrayim's letters in her Egyptian corpus). 
TABLE 3 Representation of the definite article in merchants' letters, the writers (cont.)

\begin{tabular}{|c|c|c|c|c|}
\hline & $\begin{array}{l}\text { Name \& place of } \\
\text { birth (if known) }\end{array}$ & Classmark & $\begin{array}{l}\text { Date (if } \\
\text { known) }\end{array}$ & $\begin{array}{l}\text { Separated definite } \\
\text { article (yes/no) }\end{array}$ \\
\hline 87 & $\begin{array}{l}\text { Yešūa b. Ismāill } \\
\text { al-Mahmūrī, active } \\
\text { in Alexandria until } \\
\text { his death in } 1090 \\
\text { CE (see Goldberg } \\
\text { 2012:120-123). }\end{array}$ & $\begin{array}{l}\text { BL Or.5542.27 } \\
\text { Moss. II.131.2 } \\
\text { CUL T-S 13J19.20 } \\
\text { JTS ENA } 2727.6 \mathrm{~b} \\
\text { JTS ENA } 2805.23 \\
\text { CUL T-S } 12.389 \\
\text { (possibly several } \\
\text { different hands) }\end{array}$ & 1080 CE & $\begin{array}{l}\text { Occasional } \\
\text { separation, but } \\
\text { generally attached }\end{array}$ \\
\hline 88 & $\begin{array}{l}\text { Mardūk b. Mūsa } \\
\text { l-Ațrābulsī (see } \\
\text { Penn. Halper } 385 \text { ) } \\
\text { is known to have } \\
\text { lived and worked } \\
\text { in Alexandria. }\end{array}$ & $\begin{array}{l}\text { BL Or.5566 B.31 } \\
\text { CUL T-S } 12.254 \\
\text { CUL T-S } 12.373 \text { (as } \\
\text { scribe) } \\
\text { CUL T-S 13J15.19 } \\
\text { CUL T-S 13J17.1 } \\
\text { Moss. II.154.2 } \\
\text { JTS ENA 2805.5b } \\
\text { JTS ENA 4010.21 } \\
\text { JTS ENA 4100.24b } \\
\text { Penn. Halper } 385 \\
\text { (possibly several } \\
\text { different hands) }\end{array}$ & $\begin{array}{l}1065 \mathrm{CE} \\
1048 \mathrm{CE} \\
1066 \mathrm{CE}\end{array}$ & $\begin{array}{l}\text { Tends towards } \\
\text { separation, } \\
\text { but sometimes } \\
\text { attached }\end{array}$ \\
\hline 89 & Raḥamīm b. Imrān & CUL T-S 8J26.13 & $1055 \mathrm{CE}$ & Yes \\
\hline 90 & $\begin{array}{l}\text { Hayyim b. 'Eli } \\
\text { ha-Kohen b. } \\
\text { Hayyim, writing } \\
\text { from Alexandria. }\end{array}$ & CUL T-S 13J16.2 & ca. 108 o CE & $\begin{array}{l}\text { Slight tendency } \\
\text { towards separation, } \\
\text { but generally } \\
\text { attached }\end{array}$ \\
\hline 91 & $\begin{array}{l}\text { 'Awād b. Hananāl, } \\
\text { known to have } \\
\text { lived and worked } \\
\text { in Alexandria as an } \\
\text { adult. }\end{array}$ & $\begin{array}{l}\text { CUL T-S } 16.302 \\
\text { CUL T-S } 10 J 17.21 \\
\text { CUL T-S } 12.721\end{array}$ & $\begin{array}{l}1060 \mathrm{CE} \\
1060 \mathrm{CE}\end{array}$ & $\begin{array}{l}\text { Generally attached, } \\
\text { only occasionally } \\
\text { separated (see CUL } \\
\text { T-S } 12.721 \text { verso, } \\
\text { lines } 2-3 \text { ) }\end{array}$ \\
\hline
\end{tabular}


TABLE 3 Representation of the definite article in merchants' letters, the writers (cont.)

\begin{tabular}{llll}
\hline $\begin{array}{l}\text { Name \& place of } \\
\text { birth (if known) }\end{array}$ & Classmark & $\begin{array}{l}\text { Date (if } \\
\text { known) }\end{array}$ & $\begin{array}{l}\text { Separated definite } \\
\text { article (yes/no) }\end{array}$ \\
\hline $92 \quad \begin{array}{l}\text { Abū l-Kayr b. } \\
\text { 'Awād b. Ḥananāl }\end{array}$ & $\begin{array}{l}\text { CUL T-S 10J18.16 (as } \\
\text { scribe for his father) } \\
\text { CUL T-S 1OJ10.27 (as } \\
\end{array}$ & Yes \\
& $\begin{array}{l}\text { scribe for his father?) } \\
\text { CUL T-S Misc.25.62 }\end{array}$ & \\
& & \\
\hline
\end{tabular}

TABLE 4 Representation of the definite article in Egyptian, Palestinian, and Iraqi Jewish writers' documents

\begin{tabular}{|c|c|c|c|c|}
\hline & $\begin{array}{l}\text { Name \& place of } \\
\text { birth (if known) }\end{array}$ & Classmark & Date & $\begin{array}{l}\text { Separated definite } \\
\text { article (yes/no) }\end{array}$ \\
\hline 93 & $\begin{array}{l}\text { Hai b. Širīra (a.k.a. } \\
\text { Hai Gaon) }\end{array}$ & $\begin{array}{l}\text { CUL T-S } 10 \mathrm{~J} 27.10 \\
\text { Moss. VII.157 } \\
\text { Moss. Ia.5 } \\
\text { (Two - three different } \\
\text { hands) }\end{array}$ & $\begin{array}{l}1018 \mathrm{CE} \\
1037 \mathrm{CE} \\
1037 \mathrm{CE}\end{array}$ & $\begin{array}{l}? \\
\text { No } \\
\text { No }\end{array}$ \\
\hline 94 & $\begin{array}{l}\text { (Abū Zikrī) } \\
\text { Yahūda b. Sa'adya } \\
\text { ha-Rofe }^{55}\end{array}$ & Bodl. Ms Heb.11/9 & & No \\
\hline 95 & $\begin{array}{l}\text { Mevorak b. } \\
\text { Sacadya }^{56}\end{array}$ & CUL T-S 13J16.21 & $\begin{array}{l}11 \text { th century } \\
\text { CE }\end{array}$ & No \\
\hline
\end{tabular}

55 (Abū Zikrī) Yahūda b. Sa'adya ha-Rofe (b. ca. 1025 CE and d. ca. 1077-1079 CE) (see Cohen 1980:155).

56 According to Cohen (1980:155), Mevorak b. Sa'adya was the son of Sa'adya ('the physician')

b. Mevorak, and half-brother to Yahūda b. Sa'adya. 
TABLE 4 Representation of the definite article in Egyptian, Palestinian, and Iraqi (cont.)

\begin{tabular}{|c|c|c|c|c|}
\hline & $\begin{array}{l}\text { Name \& place of } \\
\text { birth (if known) }\end{array}$ & Classmark & Date & $\begin{array}{l}\text { Separated definite } \\
\text { article (yes/no) }\end{array}$ \\
\hline 96 & $\begin{array}{l}\text { Natan ha-Kohen b. } \\
\text { Mevorak }\end{array}$ & $\begin{array}{l}\text { CUL T-S 13J14.13 } \\
\text { CUL T-S 10J5.21 } \\
\text { CUL T-S 8J39.1 } \\
\text { CUL T-S 18J2.3 (scribe } \\
\text { for Abraham b. Halfon b. } \\
\text { Nahūm) } \\
\text { BL Or. 5544.3 } \\
\text { Bodl. Ms Heb.c.28/65 } 57 \\
\text { CUL Or.1081J18 } \\
\text { JTS ENA 2727.35 }\end{array}$ & $\begin{array}{l}\text { ca. } 1090 \mathrm{CE} \\
\text { ca. } 1110 \mathrm{CE}\end{array}$ & No \\
\hline 97 & Mevorak b. Natan & $\begin{array}{l}\text { CUL T-S } 12.60 \\
\text { CUL T-S AS } 145.6 \\
\text { CUL T-S } 13 \text { J20.6 } \\
\text { JTS ENA NS } 69.12^{58}\end{array}$ & $1180 \mathrm{CE}$ & No \\
\hline 98 & $\begin{array}{l}\text { Yūsuf ha-Kohen } \\
\text { b. Šelomo Goan, } \\
\text { Palestine }\end{array}$ & CUL T-S 13J8.30 & $1050 \mathrm{CE}$ & No \\
\hline 99 & $\begin{array}{l}\text { Elijah ha-Kohen b. } \\
\text { Šelomo (brother of } \\
\text { Yūsuf) }\end{array}$ & CUL T-S 13J18.28 & $1030 \mathrm{CE}$ & No \\
\hline 100 & $\begin{array}{l}\text { Abiathar } \\
\text { ha-Kohen }\end{array}$ & CUL T-S 24.49 & $1070 \mathrm{CE}$ & No \\
\hline 101 & $\begin{array}{l}\text { Ibrahīm b. Šelomo } \\
\text { b. Yahūda }\end{array}$ & CUL T-S NS J91 & $1050 \mathrm{CE}$ & No \\
\hline
\end{tabular}

57 See Cohen (1980:316-321) for a translation of this letter.

$5^{8}$ This fragment has been recently identified by Ashur \& Zewi as a fragment of Sacadya's translation of the Pentateuch (Numbers 27:18-22, 28:2-7) (2019:113). Ashur \& Zewi also identify the scribe as Mevorak b. Natan (ibid.) and note b. Natan's tendency to separate the definite article from the noun/adjective at the end of a textline (see ibid.:117, n. 9 and n. 26). I am grateful to one of this article's anonymous reviewers for directing me to Ashur \& Zewi's article and for pointing out this feature of b. Natan's writing, noted by Ashur \& Zewi. 
TABLE 4 Representation of the definite article in Egyptian, Palestinian, and Iraqi (cont.)

\begin{tabular}{|c|c|c|c|c|}
\hline & $\begin{array}{l}\text { Name \& place of } \\
\text { birth (if known) }\end{array}$ & Classmark & Date & $\begin{array}{l}\text { Separated definite } \\
\text { article (yes/no) }\end{array}$ \\
\hline 102 & $\begin{array}{l}\text { 'Eli ha-Kohen b. } \\
\text { Ezekiel, Palestine }\end{array}$ & $\begin{array}{l}\text { CUL T-S AS } 147.2 \\
\text { CUL T-S } 10 \mathrm{~J} 19.16 \\
\text { CUL T-S } 13 \mathrm{~J} 15.23 \\
\text { CUL T-S } 10 \mathrm{~J} 29.5 \\
\text { CUL T-S } 13 \mathrm{~J} 36.6\end{array}$ & $\begin{array}{l}\text { ca. } 1055 \mathrm{CE} \\
1060 \mathrm{CE} \\
1071 \mathrm{CE} \\
\text { ca. } 1060 \mathrm{CE}\end{array}$ & No \\
\hline 103 & $\begin{array}{l}\text { Abraham b. Natan } \\
\text { (b. Abraham) Av, } \\
\text { Palestine }^{59}\end{array}$ & $\begin{array}{l}\text { CUL T-S } 10 J 13.11 \\
\text { CUL T-S } 1 \mathrm{OJ} 27.11 \\
\text { CUL T-S } 10 \mathrm{~J} 27.3 \\
\text { CUL T-S } 18 \mathrm{~J} 1.17 \\
\text { CUL T-S } 20.121 \\
\text { JTS ENA } 1822 \mathrm{a} .44 \\
\text { JTS ENA } 1822 \mathrm{a} .45 \\
\text { JTS ENA NS } 2.9 \\
\text { Moss. II.152.2 } \\
\text { Moss. VII.74.1 } \\
\text { Stras. } 4038 / 10 \\
\text { CUL T-S } 10 \mathrm{OJ} 9.33 \\
\text { CUL T-S AS } 145.8\end{array}$ & $\begin{array}{l}1105 \mathrm{CE} \\
1102 \mathrm{CE}\end{array}$ & No \\
\hline 104 & $\begin{array}{l}\text { Arah b. Natan } \\
\text { (a.k.a. Musāfir b. } \\
\text { Wahb; brother of } \\
\text { Abraham b. Natan } \\
\text { 'the seventh') }\end{array}$ & $\begin{array}{l}\text { CUL T-S NS J24a; CUL } \\
\text { T-S NS J24b } \\
\text { CUL T-S } 13 \mathrm{~J} 22.23\end{array}$ & ca. $1100 \mathrm{CE}$ & No \\
\hline 105 & $\begin{array}{l}\text { Šelomo b. Yešūca, } \\
\text { ha-Haver of } \\
\text { Damīra }^{60}\end{array}$ & Bodl. ms Heb.d.66/29 & $\begin{array}{l}11 \text { th }-12 \text { th } \\
\text { century CE }\end{array}$ & No \\
\hline
\end{tabular}

59 See Cohen 1980:121-126. For a comparison of handwriting and autograph, see the legal document CUL T-S 8J4.12.

6o Identified as a Palestinian refugee by Cohen (1980:235). 
TABLE 4 Representation of the definite article in Egyptian, Palestinian, and Iraqi (cont.)

\begin{tabular}{|c|c|c|c|c|}
\hline & $\begin{array}{l}\text { Name \& place of } \\
\text { birth (if known) }\end{array}$ & Classmark & Date & $\begin{array}{l}\text { Separated definite } \\
\text { article (yes/no) }\end{array}$ \\
\hline \multirow[t]{16}{*}{106} & Daniel b. 'Azariah ${ }^{61}$ & CUL T-S 12.109 & 11 th century & No \\
\hline & & CUL T-S 16.30 & $\mathrm{CE}$ & \\
\hline & & CUL T-S 24.56 & & \\
\hline & & CUL T-S 8J19.10 & & \\
\hline & & CUL T-S $10 J_{5} .22$ & & \\
\hline & & CUL T-S $10 J 9.20$ & & \\
\hline & & CUL T-S $10 J 9.28$ & & \\
\hline & & CUL T-S $10 J 18.18$ & & \\
\hline & & CUL T-S 10J2O.8 & & \\
\hline & & CUL T-S $10 \mathrm{~J} 25.2$ & & \\
\hline & & CUL T-S 13J8.8 & & \\
\hline & & CUL T-S $13 \mathrm{~J} 25 \cdot 3$ & $1038 \mathrm{CE}$ & \\
\hline & & CUL T-S $13 \mathrm{~J} 26.2$ & & \\
\hline & & CUL T-S 13J26.18 & $1054-1055$ & \\
\hline & & CUL T-S AS 148.3 & $\mathrm{CE}$ & \\
\hline & & CUL T-S 18.Ar.(1).135 & & \\
\hline \multirow[t]{2}{*}{107} & Samuel b. Daniel & CUL T-S $13 \mathrm{~J} 17.21$ & & No \\
\hline & b. 'Azariah & & & \\
\hline \multirow[t]{3}{*}{108} & Mūsā b. Ya'qūb & CUL T-S $13 J_{18.16}$ & $1056 \mathrm{CE}$ & Yes \\
\hline & al-Mișrī & CUL T-S 13J23.6 & & \\
\hline & & CUL T-S 13J23.16 & & \\
\hline \multirow[t]{8}{*}{109} & Efrayim b. & CUL T-S 16.134 (recto) & & No \\
\hline & Šemarya & CUL T-S 20.89 & & \\
\hline & & CUL T-S 8J26.3 & & \\
\hline & & CUL T-S 13J13.13 & & \\
\hline & & CUL T-S 13J16.2O & & \\
\hline & & CUL T-S 13J26.24 & & \\
\hline & & CUL T-S 13J27.5 (verso) & & \\
\hline & & CUL T-S 13J27.14 & & \\
\hline
\end{tabular}

61 Although signed with Daniel b. 'Azariah's autograph, the main text of the letter cul T-S 13J23.4 appears to be written in a different hand. The palaeographical differences are clearest in the writing of the definite article ligature and the grapheme 'alef. In this letter, there is a tendency towards separation of the definite article from the noun. 
TABLE 4 Representation of the definite article in Egyptian, Palestinian, and Iraqi (cont.)

\begin{tabular}{|c|c|c|c|c|}
\hline & $\begin{array}{l}\text { Name \& place of } \\
\text { birth (if known) }\end{array}$ & Classmark & Date & $\begin{array}{l}\text { Separated definite } \\
\text { article (yes/no) }\end{array}$ \\
\hline \multirow{12}{*}{110} & & CUL T-S $13 \mathrm{~J} 27.16^{62}$ & ca. $1030 \mathrm{CE}$ & \\
\hline & & CUL T-S $18 \mathrm{~J} 2.12$ & & \\
\hline & & CUL T-S AS 145.94 & & \\
\hline & & CUL T-S AS 147.90 & & \\
\hline & & CUL T-S AS $151.4^{63}$ & & \\
\hline & & CUL T-S NS $98.64^{64}$ & & \\
\hline & & Moss. V.366.1 & & \\
\hline & & L-G Glass 39 & & \\
\hline & Elḥanan b. & CUL T-S 16.134 (verso) & & No \\
\hline & Šemarya $^{65}$ & CUL T-S 8J7.13 & & \\
\hline & & CUL T-S 8J22.14 (verso) & & \\
\hline & & CUL T-S 20.40 (recto) & & \\
\hline \multirow[t]{7}{*}{111} & Yefet b. David b. & CUL T-S 12.74 & ca. $1007^{-}$ & No \\
\hline & Šeknanya & CUL T-S 16.45 & $1010 \mathrm{CE}$ & \\
\hline & & CUL T-S 8J29.12 & & \\
\hline & & CUL T-S 13J6.23 & & \\
\hline & & CUL T-S 13J27.5 (recto) & ca. $1008-$ & \\
\hline & & CUL T-S $13 \mathrm{~J} 35.2$ & $1011 \mathrm{CE}$ & \\
\hline & & CUL T-S NS J51 & $1027 \mathrm{CE}$ & \\
\hline \multirow[t]{2}{*}{112} & 'Eli ha-Mumhe b. & Moss. II.137.1 & $1054 \mathrm{CE}$ & No \\
\hline & Abraham & CUL T-S 13J27.6 & ca. $1045 \mathrm{CE}$ & \\
\hline
\end{tabular}

62 CUL T-S 13J27.16 is attributed to 'Eli ha-Kohen b. Ezekiel by Goitein and to Yefet b. David by Bareket. However, I think it might be in Efrayim b. Šemarya's hand.

63 Previously assigned to Yefet b. David.

64 Previously (tentatively) attributed to Yefet b. David.

65 See the Hebrew letter CUL T-S 18J4.5 for a further example of Elḥanan b. Šemarya's autograph. 
TABLE 4 Representation of the definite article in Egyptian, Palestinian, and Iraqi (cont.)

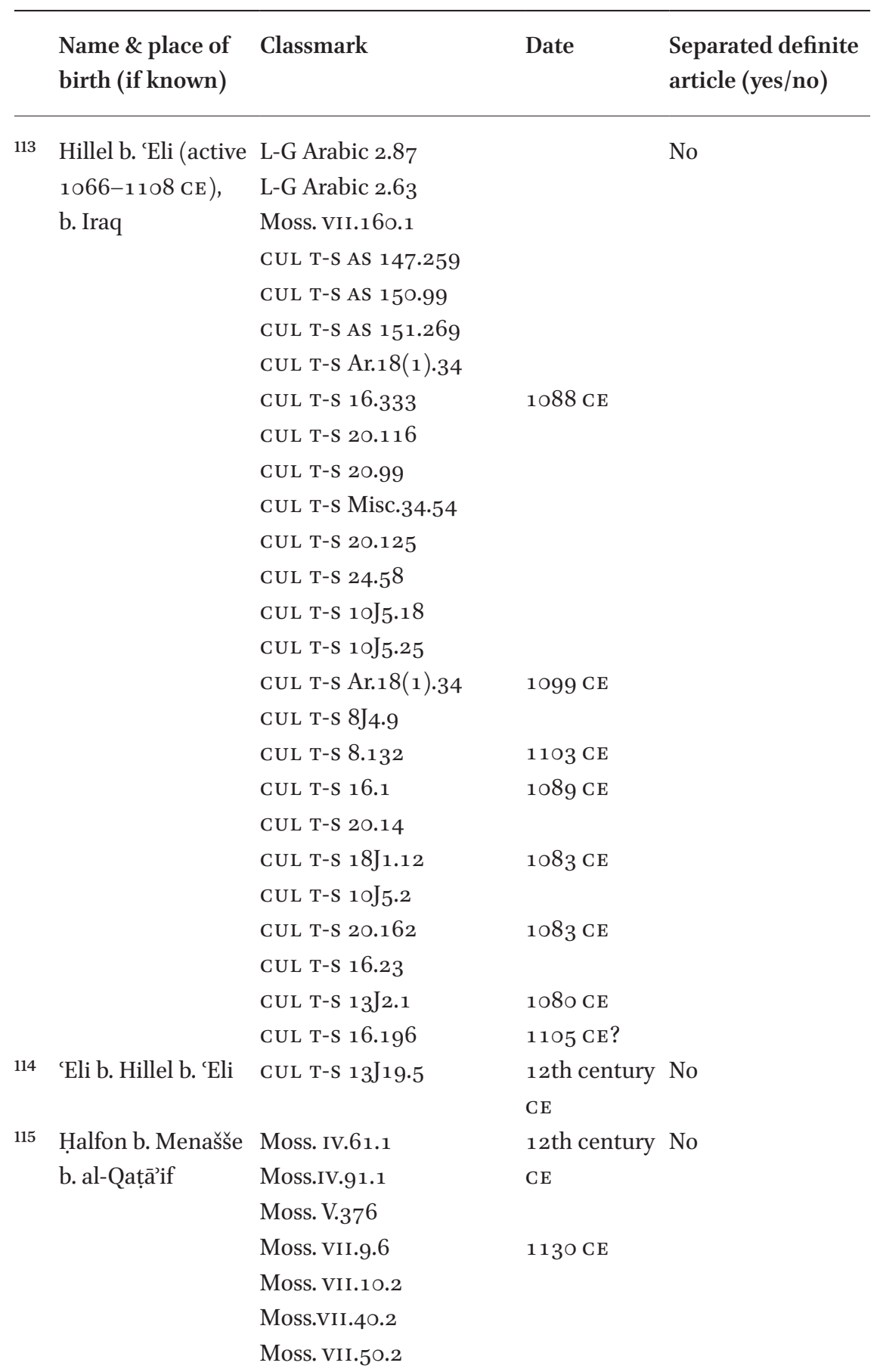


TABLE 4 Representation of the definite article in Egyptian, Palestinian, and Iraqi (cont.)

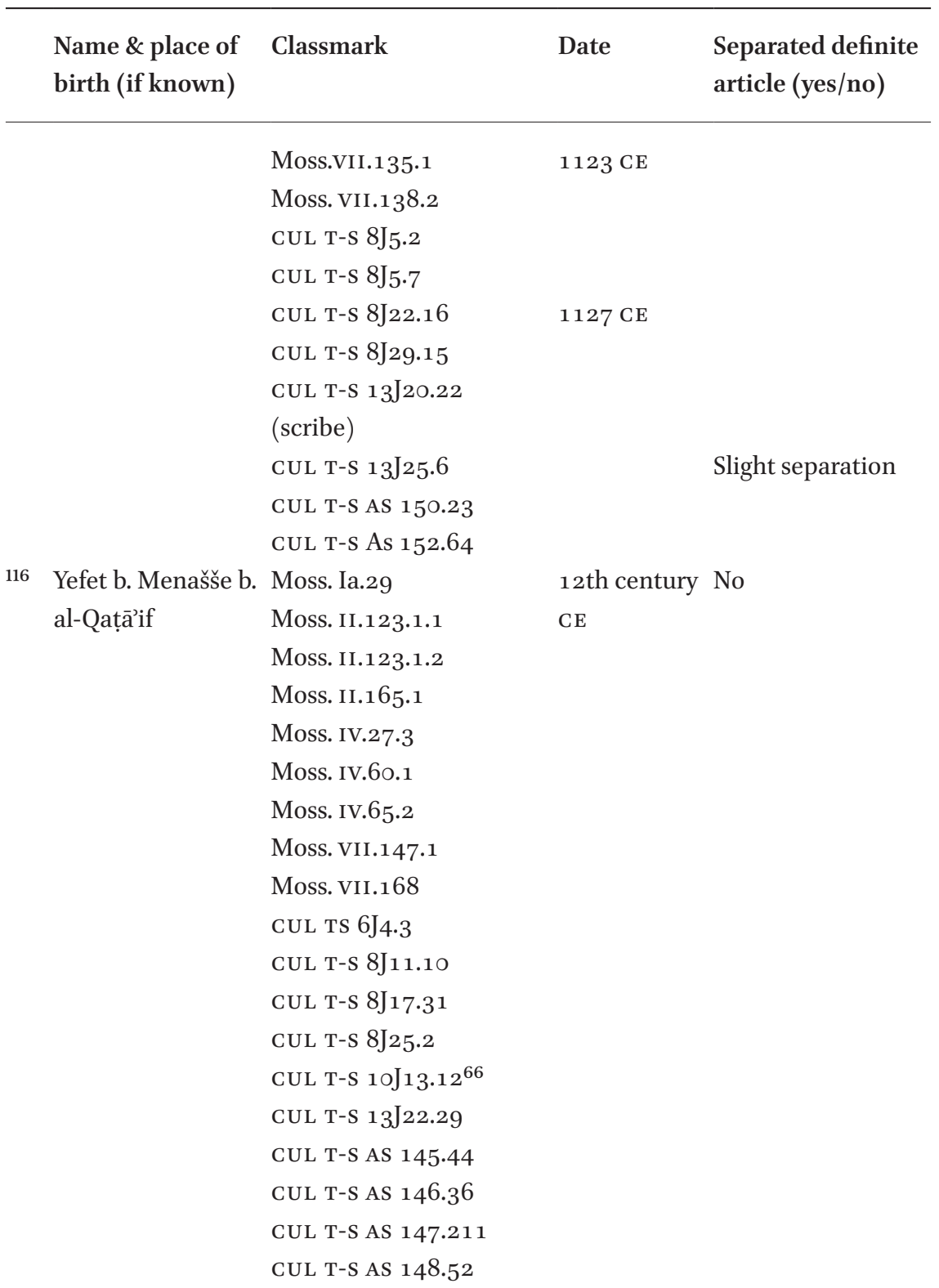

66 In the writing of his name on verso, Yefet b. Menašše b. al-Qațāif slightly separates the definite article from his family name al-Qatạaifif. This is the only instance in which al-Qatạâif does this that I have encountered. 
TABLE 4 Representation of the definite article in Egyptian, Palestinian, and Iraqi (cont.)

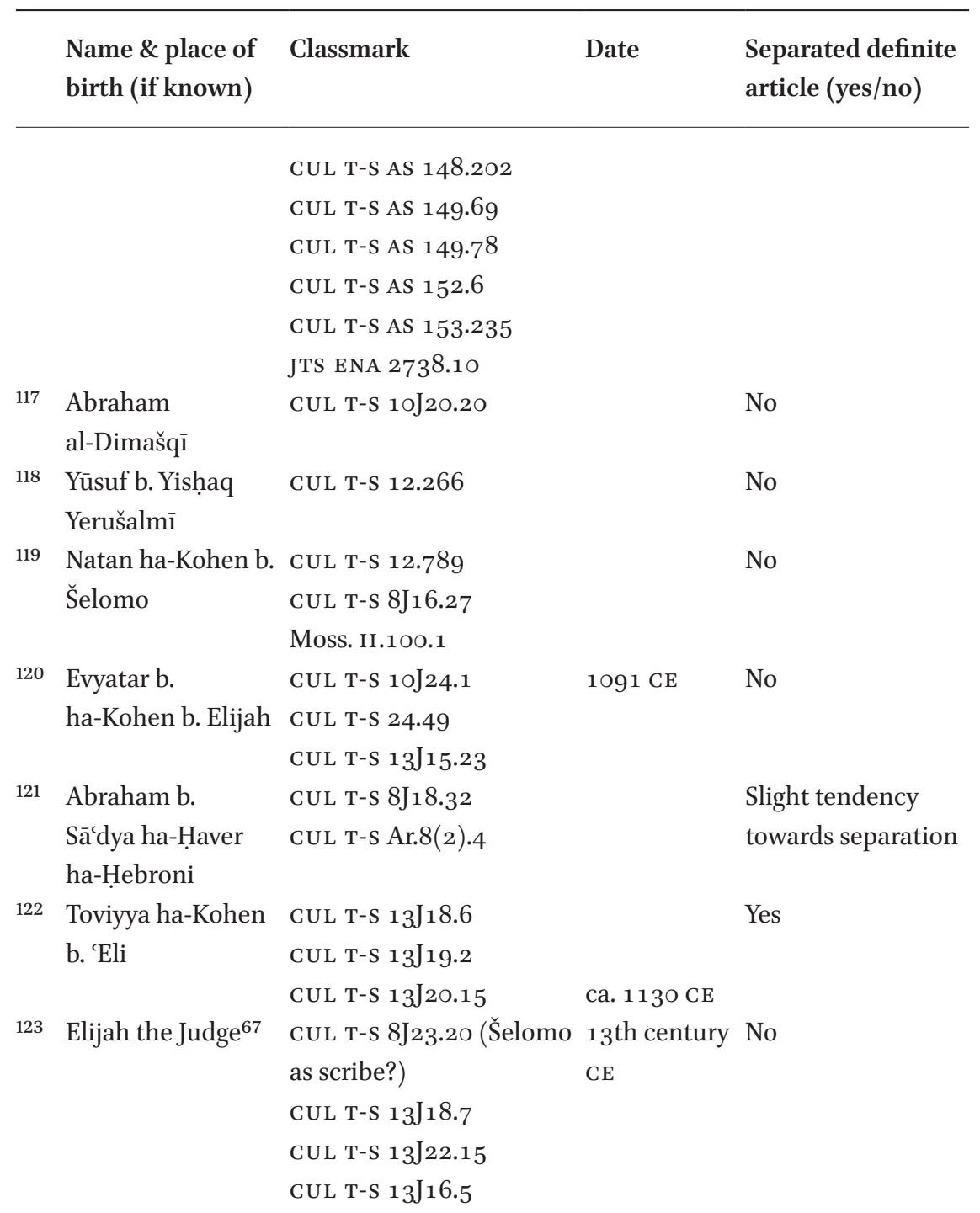

67 Elijah the Judge is addressed as al-Iskandarānī by his brother-in-law Manșūr b. Sālim (see CUL T-S 1OJ14.12 verso). 
TABLE 4 Representation of the definite article in Egyptian, Palestinian, and Iraqi (cont.)

\begin{tabular}{|c|c|c|c|c|}
\hline & $\begin{array}{l}\text { Name \& place of } \\
\text { birth (if known) }\end{array}$ & Classmark & Date & $\begin{array}{l}\text { Separated definite } \\
\text { article (yes/no) }\end{array}$ \\
\hline 124 & $\begin{array}{l}\text { Šelomo b. Elijah } \\
\text { the Judge }\end{array}$ & $\begin{array}{l}\text { CUL T-S 8J13.24 } \\
\text { CUL T-S 8J23.18 } \\
\text { CUL T-S 8J41.8 } \\
\text { CUL T-S 13J7.26 } \\
\text { CUL T-S 13J22.5 } \\
\text { CUL T-S 13J22.34 } \\
\text { CUL T-S 13J28.19 } \\
\text { Moss. II.135.1 recto } \\
\text { Moss. II.155.2 verso } \\
\text { Moss. VII.139.1 } \\
\text { CUL T-S AS } 151.198 \\
\text { verso } \\
\text { CUL T-S AS } 149.176 \\
\text { recto } \\
\text { CUL T-S AS } 145.78 \text { recto } \\
\text { CUL T-S NS J45 recto } \\
\text { CUL T-S NS J102 }\end{array}$ & $\begin{array}{l}13^{\text {th century }} \\
\mathrm{CE}\end{array}$ & No \\
\hline 125 & Manșūr b. Sālim & $\begin{array}{l}\text { CUL T-S } 10 \mathrm{~J} 13.10 \\
\text { CUL T-S } 10 \mathrm{~J} 14.10 \\
\text { CUL T-S Ar.18(1).137 }\end{array}$ & $\begin{array}{l}13^{\text {th century }} \\
\mathrm{CE}\end{array}$ & No \\
\hline
\end{tabular}

\section{Magdalen Connolly}

is a Leverhulme Early Career Fellow at FAMEs, University of Cambridge, where she researches written linguistic features of Egyptian Jewish, Muslim, and Christian folk tales from the pre-modern era. She gained a first-class degree in Arabic and Theology at the University of Exeter (2013). After completing her MPhil (2013-2014) and PhD (2014-2018) in Judeo-Arabic philology, under the supervision of Prof. Geoffrey Khan at Emmanuel College, Magdalen became a part-time Research Associate at the Genizah Research Unit. 